\title{
THE EMERGENCE OF UNJUST ENRICHMENT AS A CAUSE OF ACTION AND THE REMEDY OF CONSTRUCTIVE TRUST
}

\author{
M.M. LITMAN*
}

\begin{abstract}
The author discusses the emergence of unjust enrichment as a cause of action in Canada today. He offers a substantive analysis of the action from both doctrinal and policy viewpoints, both in the commercial and cohabitational contexts. The remedy of constructive trust is examined in a similar manner.
\end{abstract}

TABLE OF CONTENTS

PAGE

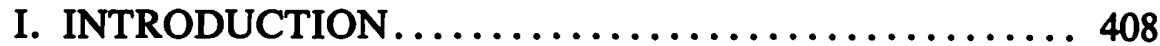

II. THE HISTORICAL CONTEXT OF THE DEVELOPMENT OF UNJUST ENRICHMENT ....... 411

A. QUASI-CONTRACT AND UNJUST ENRICHMENT. 411

B. RESULTING TRUSTS AND UNJUST ENRICHMENT.

C. CONSTRUCTIVE TRUSTS AND UNJUST ENRICHMENT.

III. THE CONTEMPORARY RELATIONSHIP BETWEEN UNJUST ENRICHMENT AND THE TRADITIONAL

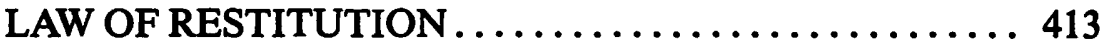

A. THE RELATIONSHIP BETWEEN THE COMMON INTENTION RESULTING TRUST AND THE RESTITUTIONARY CONSTRUCTIVE TRUST ..... 415

B. THE RELATIONSHIP BETWEEN THE INSTITUTIONAL CONSTRUCTIVE TRUST AND

THE RESTITUTIONARY CONSTRUCTIVE TRUST. 415

IV. THE CONCEPTS OF DEPRIVATION AND

ENRICHMENT .

A. DEPRIVATION ....................... 418

1. The General Concept.................... 418

2. Deprivation of Money and Property .......... 419

3. Intangible Contributions................ 420

4. Interceptive Subtraction ................ 421

B. ENRICHMENT ....................... 425

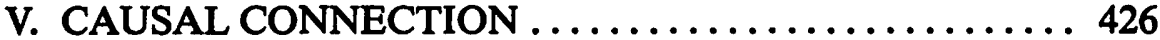

A. THE ERROR OF REQUIRING A CONNECTION BETWEEN THE PLAINTIFF'S CONTRIBUTION AND THE DEFENDANT'S PROPERTY ........ 426

B. PROXIMATE CAUSE ................... 429

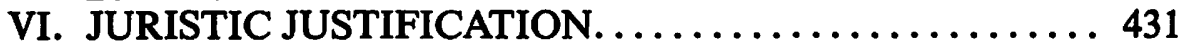

A. ONUS OF PROOF $\ldots \ldots \ldots \ldots \ldots \ldots \ldots \ldots \ldots \ldots, 431$

B. NATURE OF JURISTIC JUSTIFICATION ........ 434

C. CATALOGUE OF JURISTIC JUSTIFICATIONS ..... 436

D. RECOVERY FOR DOMESTIC OR HOUSEKEEPING SERVICES

- Professor of Law, University of Alberta, Faculty of Law. Earlier drafts of this paper were presented to the Canadian Bar Association, Saskatchewan Mid-Winter Meeting (February, 1988) and the Canadian Association of Law Teachers Meeting (June, 1988). 
E. JURISTIC JUSTIFICATION AND STATUTORY

POLICY ............................. 442

1. Unjust Enrichment and Matrimonial Property

Statutes ......................... 442

2. Unjust Enrichment and Other Statutes ......... 447

F. JURISTIC JUSTIFICATION AND THE INTENTION OF THE PARTIES . ................... 449

G. LIMITS OF JURISTIC JUSTIFICATION ........ 451

VII. REMEDYING UNJUST ENRICHMENT: THE

PROPRIETARY AND PERSONAL REMEDIES ........ 454

A. THE PRESUMPTION IN FAVOUR OF THE

PERSONAL REMEDY ...................... 454

B. PROPRIETARY REMEDIES .............. 456

1. Timing of Acquisition of Beneficial Interest ......460

(a) The Insolvency Context $\ldots \ldots \ldots \ldots \ldots \ldots, 463$

(b) Third Party Transferees .............. 465

C. QUANTIFICATION OF REMEDIES ........... 466

VIII. CONCLUSION ....................... 468

\section{INTRODUCTION}

In 1980 the Supreme Court of Canada, in the case of Pettkus v. Becker,' elevated unjust enrichment from an underlying principle of the legal system to a full fledged cause of action. The analytical components of this cause of action are presently being shaped and defined. It appears clear that unjust enrichment will develop, if it has not already, into a vital force in the private law system. To this point it has had a major, albeit somewhat controversial, impact on the economic consequences of family relationships, usually involving non-marital cohabitation. It should not be surprising that these relationships are being scrutinized with a view to rectifying the adverse economic consequences suffered by the parties to these relationships. Such rectification is warranted as the reality of family life is that it often has hidden economic consequences which are not fairly reflected in "the state of title". It is vital to realize that the purpose of the law of unjust enrichment in this context is not to re-define the nature of social relationships, but rather to regulate fairly, some of the economic consequences of intimate social life. In the business or commercial context, the law of unjust enrichment has been less controversial, at least in part, because commercial relationships are generally viewed as being "purely" economic in nature. Fair economic regulation of these relationships is not considered to be invasive of the social fabric.

The importance of the law of unjust enrichment stems from its substantive merit and conceptual breadth. It gives expression to the trite but deeply felt socio-economic and philosophical conviction that one should not reap what others have sown. As Laskin C.J. stated in Rathwell v. Rathwell, "[a]s a matter of principle, the court will not allow any man

1. [1980] 2 S.C.R. 834, (1980) 117 D.L.R. (3d) 257, E.T.R. 143. 
unjustly to appropriate to himself the value earned by the labour of others."2 More generally, benefits generated by a person's investment of time, effort and property should, in the absence of compelling reasons, belong to that person and no other. The contrary conclusion would be patently unfair, demoralizing and, perhaps, even economically inefficient. It is suggested that appreciation of these very basic, yet fundamental points can assist in providing proper guidance to and clarity in the emerging law of unjust enrichment. Though it is always important to focus on the purpose of legal doctrine, in the formative years of the development of doctrine this focus must, above all else, be clear and constant.

The doctrinal elements of unjust enrichment were set out by Dickson C.J. in Pettkus v. Becker. These now familiar elements are: ${ }^{3}$

(i) enrichment;

(ii) deprivation;

(iii) causal connection between enrichment and deprivation; and

(iv) absence of juristic justification for the enrichment.

In retrospect, it is clear that this outline of the cause of action is skeletal in nature and that Pettkus v. Becker is merely a narrow example of this cause of action at work. While most of the cases decided since Pettkus v. Becker have been sensitive to the breadth of the various constituent elements of unjust enrichment, this has not been universally true. In several early cases and, indeed, more recently, the concept of enrichment has been interpreted unduly restrictively. Moreover, particularly in the matrimonial and quasimatrimonial context, too often there seems to have been a failure to appreciate that the concepts of enrichment and deprivation, because of their substantive content, are so inter-connected, that the one is merely the "flip side" of the other. It follows that in this context when a deprivation exists, enrichment should invariably be present. On the other hand, in the non-matrimonial context, lawyers seem to have overestimated the breadth of the "causal connection" requirement. As a result, unjust enrichment actions which were doomed to failure were initiated. Moreover, in respect to "juristic justification", the final element of unjust enrichment, the cases suggest that there may be confusion relating to which party bears the burden of proof. This confusion stems from "mixed signals" emanating from Dickson C.J's judgment in Pettkus v. Becker. This article will review the development of the various component parts of the cause of action of unjust enrichment, developing the assertions made above.

Another focus of this article will be the question of whether the action of unjust enrichment has reintroduced the "Chancellor's foot" into the civil justice system. Mr. Justice Martland, in his minority opinion in Pettkus v. Becker, warned that recognizing an action for unjust enrichment would produce "palm tree justice". 4 This was not a new criticism. In England, unjust enrichment, even as a mere rationalizing principle of law, was, and in some quarters still is, considered to be "too nebulous and broad" to be

2. [1978] 2 S.C.R. 436 at 455, 2 W.W.R. 101, 83 D.L.R. (3d) 289.

3. Supra, n. 1, S.C.R. at 848 .

4. Id. at 859. 
of utility in an "inductive system like the common law". The fear is that of subjective and intuitive decision-making and, therefore, inconsistent, uncertain, and even worse, potentially arbitrary results. ${ }^{6}$ Though on the whole the cases decided since Pettkus v. Becker have been remarkably free of these defects, recent developments will undoubtedly be viewed by some as the realization of Martland J's worst fears and best prognostications.

This article will also consider the remedial alternatives available in cases of unjust enrichment. Just as contract and tort law have available to them an array of remedies to correct wrongdoing, there are various restitutionary remedies available to correct unjust impoverishment. In Pettkus v. Becker the proprietary remedy of constructive trust was utilized. Why this proprietary remedy was preferred over the personal remedy of monetary damages, or, for that matter, why the proprietary remedy of constructive trust was preferred over the proprietary remedy of equitable lien, was not discussed by the Court. In subsequent cases both proprietary and/or personal remedies have been employed but, unfortunately, the judiciary has not as yet articulated workable guidelines as to the appropriate remedy. Failure to develop such guidelines and the close association that the remedy of constructive trust has had with cases of unjust enrichment has had an indirect cost. It appears that some courts have equated the proprietary remedy of constructive trust with the substantive wrong of unjust enrichment. In at least two cases plaintiffs were denied relief for precisely this reason. The denial stemmed from the standard trust law requirement that trust property be identifiable. As will be noted in the discussion of remedies, it is at least arguable that the restitutionary constructive trust is not a standard proprietary remedy and, therefore, its existence does not inevitably depend on the ability of a complainant to establish a causal connection between his or her contribution and specific property in the defendant's name.

An additional issue which this article will consider is whether the equitable interest of a constructive trust beneficiary arises upon judicial declaration of the trust or upon the occurrence of the deprivation and corresponding enrichment which gives rise to the trust. The answer to this question has important implications not only for the trustee of the constructive trust and the beneficiary, but also for third parties who either have claims against the assets of constructive trustees or have acquired property from constructive trustees. Third party claimants include, purchasers of the subject matter of constructive trusts, creditors of bankrupt constructive trustees and secured creditors of such constructive trustees, including those claiming under personal property security legislation.

Finally, another issue of general import will be considered. What is the relationship between the pre-Pettkus v. Becker law of restitution and the law of unjust enrichment which post-dates this case? On this point this

5. Waters, Law of Trusts in Canada, (2nd ed., 1984) 382.

6. See Professor David Haydon's recent paper "Constructive Trusts: Is the Remedying of Unjust Enrichment a Satisfactory Approach", presented to the International Symposium on Trusts, Equity and Ficuciary Relationships (University of Victoria, B.C., February, 1988) where some of these criticisms are made. In particular see page 4 of his paper. 
article will touch on the relationship between the modern remedial or restitutionary constructive trust and the old resulting and "institutional" constructive trusts.

\section{THE HISTORICAL CONTEXT OF THE DEVELOPMENT OF UNJUST ENRICHMENT}

It is widely acknowledged that fear of the concept of unjust enrichment has caused English courts to resort to fictitious and artificial reasoning to correct specific instances of unjust enrichment. The result of this indirect approach has been the development of wholly inappropriate doctrine, the creation of conceptual confusion and the retardation of the pace of development of a comprehensive and cogent law of unjust enrichment.

\section{A. QUASI-CONTRACT AND UNJUST ENRICHMENT}

Historically, one of the major prophylactic responses to English law was to attribute restitution to the rubric of contract law. To be more specific, legal actions based on quantum meruit or for "money had and received" were developed and characterised as being "quasi-contractual" in nature." While the particular legal pigeon-hole assigned to an action is not of overwhelming importance, there are dangers if the assignment is conceptually inappropriate. Confusion can easily result when an action is associated with a functionally unrelated area of law. More importantly, there is a danger of seepage of doctrine from the broader category into the cause of action. Unfortunately, in the quasi-contractual area there has been considerable doctrinal spillover. For example, the restitutionary doctrine of privity of mistake owes its life-blood to the contrived association of restitutionary law with contract law. Goff and Jones refer to this doctrine as an "unintelligible" "relic of the heresy of implied contract". ${ }^{8}$ Without purusing the substantive content of this doctrine, its current status under existing Canadian law or any possible underlying substantive justification for it in a restitution context, its mere existence illustrates the danger of the fiction that the law of restitution is somehow related to contract law. ${ }^{9}$

\section{B. RESULTING TRUSTS AND UNJUST ENRICHMENT}

In the context of matrimonial property actions, the English law's fear of unjust enrichment had the effect of altering the conceptual structure of the resulting trust. The standard resulting trust arises from the presumed intention ${ }^{10}$ of the transferor of property and not because of the joint

7. Goff and Jones, The Law of Restitution, (2nd ed., 1978) at 3.

8. Id. at 32 .

9. The need under the law of quasi-contract to establish an implied contract or an agency of necessity in order to obtain restitituion for an unsolicited benefit is but another example of inappropriate seepage of doctrine. For the implied contract requirement see Falcke v. Scottish Imperial Insurance Co. (1886) 34 Ch.D. 234 (H.L.), and for the agency of necessity point see Hastings v. Village of Seamans (1946) 4 D.L.R. 695 (Sask. C.A.).

10. Arguably, the intention underlying resulting trusts is imputed rather than presumed or implied. See J. Stone, Legal System and Lawyers Reasoning, (1964) Ch. VII, where it is suggested that the distinction between inferred and imputed intention is extremely technical and ultimately illusory. 
intentions of the transferor and transferee. "Equity presumes bargains and not gifts and, therefore, it follows that when A gratuitously transfers property to $B$, equity presumes, in the absence of evidence to the contrary, that B holds the property on trust for A. Similarly, if A establishes a trust, which upon termination does not exhaust the subject matter, the trustee holds the remaining property on trust for A. ${ }^{12}$ Again the justification for this resulting trust is the intention (albeit presumed) of A, the transferor. In the early 1970s, English courts were faced with cases in which one spouse, usually the husband, had acquired title to matrimonial property obtained through the joint efforts of both spouses. These cases of unjust enrichment were initially resolved, not with a frontal assault on the "fact" of unjust enrichment, but indirectly through the artificial and unorthodox invocation of the resulting trust. The "common intention resulting trust" would arise said Lord Diplock, in Gissing v. Gissing, in:13

... cases where the court is satisfied by the words or conduct of the parties that it was their common intention that the beneficial interest was not to belong solely to the spouse in whom the legal estate was vested but was to be shared by them in some proportion or other.

This approach is problematic. Why such an intention, if it exists, does not ordinarily give rise to an express trust is puzzling. ${ }^{14}$ Moreover, as noted above, the common intention resulting trust lacks conceptual fidelity to the classic resulting trust. ${ }^{13}$ Most important, the common intention described by Lord Diplock rarely exists. Therefore, in cases where claimants are deserving of relief because their efforts have enriched defendants, there will be a "natural" tendency for courts to fabricate or fictionalize ${ }^{16}$ the existence of such intention. ${ }^{17}$ Despite these drawbacks the majority of the Supreme Court of Canada in the case of Murdoch v.

11. Supra, n. 5 at 299.

12. Id. at 301 .

13. [1971] A.C. 886 at 909, [1970] 2 All E.R. 780 (H.L.).

14. See A.J. McClean, "Constructive and Resulting Trusts - Unjust Enrichment in a Common Law Relationship - Pettkus v. Becker" (1982) 16 U.B.C. Law Review, 155 at 158 where he makes this point and where he explores the analytical difficulties of the common intention resulting trust.

15. That is, the traditional resulting trust arises from the presumed (or imputed) intention of the settlor of the property and not both the settlor's intention and that of the legal title holder.

16. See Marcia Neave's recent paper "Three Approaches to Family Property Disputes Common Intention, Unjust Enrichment and Unconscionability" at p. 17, presented to the International Symposium on Trusts, Equity and Fiduciary Relationships (University of Victoria, B.C., February, 1988).

17. In England and Australia the doctrine of proprietary estoppel has also been utilized to protect the reasonable expectations of parties engendered by representations of proprietary benefit. Parties who make contributions to relationships in reliance on promises of proprietary benefit can indirectly enforce the promises with the aid of the doctrine. See Neave supra, n. 16 at p. 17. There seems to be little to commend the use of this doctrine over the common intention resulting trust as courts have been quite artificial in finding the element of "inducement" which is necessary to invoke the estoppel. See n. 16 at p. 17. In the context of property disputes between co-habitants both the estoppel and resulting trust approaches are doctrinal fictions which ultimately are designed to prevent unjust enrichment. This is apparent when one asks why the courts effectuate common intention and invoke the estoppel. 
Murdoch ${ }^{18}$ embraced Diplock's formulation. Hence, in Canada, as in England, the law of restitution has not only been misshapen by its association with the broad category of contract law, but the standard proprietary relationship of resulting trust has been distorted in concept and fictionally invoked, where it has been called upon to play a restitutionary function.

\section{CONSTRUCTIVE TRUSTS AND UNJUST ENRICHMENT}

Judicial concern over the broad and vague concept of unjust enrichment has also had an impact on the law of constructive trusts. Waters notes that traditionally such trusts were imposed in very specific instances; ${ }^{19}$ and rather than exploring the question of why, in any particular situation, the constructive trust was being imposed, courts have been preoccupied with the narrower, collateral and less meaningful question of upon whom should such trusts be visited. ${ }^{20}$ The result has been the development of the list of familiar (or conventional) constructive trust situations, which includes the profiteering fiduciary (including the trustee), the trustee $d e$ son tort, the promisor in an enforceable joint or mutual will situation, the vendor under an agreement for the sale of land (prior to transfer), the heir of an estate of a deceased person where that heir has murdered the deceased, and so on. ${ }^{21}$ Until the decision in Pettkus v. Becker this list suffered from the absence of a unifying theme. ${ }^{2}$ Law without theme or purpose cannot develop as quickly, clearly and coherently as law which has a raison d'etre. Even if the prevention of unjust enrichment was one of the goals of the law of constructive trusts, the failure to articulate this goal undoubtedly had the effect of setting back the remedial apsect of the law of unjust enrichment. Questions such as why were some cases of unjust enrichment being resolved through the use of the proprietary remedy of constructive trust and others through the use of the personal remedy of monetary damages were left to be resolved on the basis of inference.

This brief excursion into the pre-Pettkus v. Becker law of restitution has endeavoured to demonstrate that the failure to deal with the concern of unjust enrichment in a open, honest, and rigorous manner has had its price. Professor Peter Birks has neatly summarized this point: ${ }^{23}$

No subject can ever be rationally organized or intelligibly applied so long as it is dominated by the language of fiction, of deeming, and of unexplained analogy.

\section{THE CONTEMPORARY RELATIONSHIP BETWEEN UNJUST ENRICHMENT AND THE TRADITIONAL LAW OF RESTITUTION}

For all of its defects, the "old" law of restitution is comprehensive and well thought out. Accordingly, it can provide a guideline for the develop-

18. [1975] 1 S.C.R. 423 at 437, 41 D.L.R. (3d) 367, [1974] 1 W.W.R. 361, 13 R.F.L. 185.

19. Supra, n. 5 at $398-427$.

20. Id. at 380 .

21. Id. at $398-427$.

22. Id. at 377-385.

23. See Peter Birks' interesting text, An Introduction to the Law of Restitution, (1985) at 7. 
ment of modern principles of unjust enrichment. Just as it would be a mistake to accept uncritically all of the old principles of quasi-contract, resulting trusts and constructive trusts, it would be an error, perhaps a more significant error, to simply ignore these principles. Indeed, as La Forest J.A. (as he then was) implied in Whitev. Central Trust Company, ${ }^{24}$ it would be highly unrealistic to think that the courts would do so. The courts, said Mr. Justice La Forest, "will not venture far onto an uncharted sea when they can administer justice from a safe berth". ${ }^{25}$ Though the courts will undoubtedly continue to resolve unjust enrichment claims on the basis of established restitution categories, it seems probable that the importance of these categories will fade somewhat over time. Again, this is implicit in the judgment in White v. Central Trust Company: ${ }^{26}$

\begin{abstract}
... the well recognized categories of unjust enrichment must be regarded as clear examples of the more general principle that transcends them. We are currently in a similar position with regard to unjust enrichment as we are in relation to negligence where we have for some time been abandoning recourse to particularized duties in favour of a generalized duty to one's neighbour, although the process has not yet proceeded as far in the case of restitution.
\end{abstract}

It is suggested that where an established restitutionary principle is out of accord with the underlying principle of unjust enrichment, the latter will prevail.

In summary, it is my view that at its current stage of evolution the law of unjust enrichment performs two functions. First, in an area where an established restitutionary category exists it can rationalize the principles and rules therein. On this basis one would expect the restitutionary doctrine of privity of mistake to be rejected. Similarly, the existing distinction between mistake of fact and mistake of law as defences in restitutionary actions should no longer be applied. Indeed in Hydro Electric Com'n of Nepean v. Ontario Hydro, ${ }^{27}$ Mr. Justice Dickson (as he then was), in dissent, did reject this distinction as being senseless or meaningless in an action for unjust enrichment. ${ }^{28}$ Unfortunately, Estey J., speaking for the majority, refused to consider Dickson J's analysis because the appellant had only mentioned unjust enrichment once in his factum in respect to a narrow point and in oral argument did not urge the abolition of the distinction. ${ }^{29}$ Dickson J's judgment illustrates the potential rationalizing effect unjust enrichment can have on pre-existing quasi-contractual principles. Further, Estey J's approach demonstrates the need for counsel to go beyond established restitutionary doctrine and to conceptualize issues in terms of unjust enrichment.

The second function which the law of unjust enrichment can perform is to "fill in the cracks" in the legal system. That is, where there is no established restitutionary category, unjust enrichment can in and of itself

24. (1984) 17 E.T.R. 78 (N.B.C.A.).

25. Id. at 90 .

26. Id. at 96.

27. (1982) 132 D.L.R. (3d) 193 (S.C.C.).

28. Id. at 201-211.

29. Id. at 243. 
be the source of relief. This is precisely the function that the law of unjust enrichment has played in the many quasi-matrimonial cohabitation cases such as Pettkus v. Becker. In short, unjust enrichment will operate to rationalize existing restitutionary principles and to provide relief where these principles do not, but should, exist.

\section{A. THE RELATIONSHIP BETWEEN THE COMMON INTENTION RESULTING TRUST AND THE RESTITUTIONARY CONSTRUCTIVE TRUST}

In light of the predictable judicial tendency to rely on time-tested restitutionary categories it is perhaps not surprising, but nevertheless disappointing, to see continued use of the common intention resulting trust..$^{30}$ My disappointment stems primarily from the fact that, having regard to the broader doctrine of unjust enrichment, it is totally unnecessary to rely on the existence of a common intention to share property. This intention Dickson C.J. has pejoratively described as "fugitive", "artificial", "phantom" and "rarely, if ever, express."31 In any legal system which does not recognize unjust enrichment as a cause of action, the common intention resulting trust may well be a necessary judicial fiction; but, in a system which does recognize this cause of action the fiction should quickly and without ceremony be discarded.

\section{B. THE RELATIONSHIP BETWEEN THE INSTITUTIONAL CONSTRUCTIVE TRUST AND THE RESTITUTIONARY CONSTRUCTIVE TRUST}

The situation with respect to the continued use of the institutional constructive trust is considerably more complicated. Recent cases suggest that there are two, and possibly three conceptual models of the constructive trust. The first is the familiar institutional constructive trust referred to above. The second is the restitutionary constructive trust which operates as a remedy for unjust enrichment. The third is the remedial constructive trust which operates as a remedy for wrongs which are broader in concept than unjust enrichment. This is the "natural justice and equity" or "good conscience" constructive trust recognized by Lord Denning in the case of Hussey v. Palmer. ${ }^{32}$ There it was described as follows: ${ }^{33}$

... it is a trust imposed by law whenever justice and good conscience require it. It is a liberal process, founded upon large principles of equity, to be applied in cases where the legal owner cannot conscientiously keep the property for himself alone, but ought to allow another to have the property or a share in it.

It has been suggested that this broad form constructive trust forms the underpinning of the various institutional constructive trusts. ${ }^{34}$ No doubt it

30. See, for example, Novick Estate v. Lachuk Estate (1987) 55 Sask. R. 216 at 223-224 (Sask. Q.B.) and Cleveland v. Gillis Estate (1986) 74 N.S.R. (2d) and 180 A.P.R. 406 (Co. C.).

31. Supra, n. 1, S.C.R. at 842-843.

32. [1972] 1 W.L.R. 1286, 3 All E.R. 744 (C.A.).

33. Id. W.L.R. at 1289-1290.

34. Supra, n. 14, 168-169. 
[VOL. XXVI, NO. 3

can also be viewed as the base concept of the unjust enrichment or restitutionary constructive trust.

The possibility that the broad form "good conscience" trust may arise independently of unjust enrichment was recently considered in Yorkshire Trust Co. v. Empire Acceptance Corp. Ltd. ${ }^{35}$ where McLachlin J. stated, "without deciding on its validity", that the "good conscience" trust may sustain the plaintiff's case in the event that the Court erred in finding a constructive trust arising by virtue of unjust enrichment. ${ }^{36}$ One can only speculate whether Canadian courts will be receptive to a concept of this breadth. Until the "good conscience" trust can be analytically structured and it becomes possible to go beyond the bare notion of fairness in verbalizing a justification for the trust, I expect Canadian courts will be somewhat reluctant to embrace it. If this trust model is accepted there will be considerable overlap between it and the institutional and remedial constructive trusts. However, there will undoubtedly be residual cases which fit into this broad model alone.

In the post-Pettkus v. Becker era there are numerous cases where courts have used the institutional constructive trust without adverting to or relying on unjust enrichment. For example, in Ontario Wheat Producers Marketing Board v. Royal Bank of Canada ${ }^{37}$ such a trust was imposed on a bank which received money with actual knowledge that it belonged to someone other than the depositor. Utilizing a similar theory, Dohm J. in MacMillan Bloedel Ltd. v. Binstead ${ }^{38}$ required an accounting of secret profits received by individuals and companies who knowingly participated in a breach of fiduciary duty. These defendants were held to be constructive trustees on the basis of traditional constructive trust principles. What makes the MacMillan case interesting is that the trial Judge concluded, on the facts before him, that the doctrine of unjust enrichment would not warrant the imposition of trusteeship. This was so because the plaintiff company could not be said to have suffered a loss or deprivation; its own policy precluded it from receiving the profits. ${ }^{39}$ The institutional constructive trust was imposed "not to balance the equities but to ensure that trustees and fiduciaries remain faithful and that those who assist them in the breaches of their duty are called to account." ${ }^{40}$ What is implicit in this case is that unjust enrichment is not the exclusive unifying theme of the various institutional constructive trusts. This point had previously been made by Professor McClean who had suggested that unless "a rather wide and distorted view of the nature of loss is adopted", the traditional constructive trust imposed on a trustee de son tort and upon a trustee who has made an improper profit, cannot always be explained by the unjust enrichment model of constructive trust." This view is consistent with the

35. (1986) 22 E.T.R. 96 (B.C.S.C.).

36. Id. at $105-106$.

37. (1984) 9 D.L.R. (4th) 729 (Ont. C.A.).

38. (1983) 14 E.T.R. 269 (B.C.S.C.).

39. Id. at 297.

40. Id. at 302 .

41. Supra, n. 14 at 168. See also Waters, supra, n. 5 at 396 where he states that unjust enrichment is not the exclusive rationalizing principle of all institutional constructive trusts. 
recent case of McQuarrie v. Jacobs. ${ }^{42}$ There, a solicitor for the executor of an estate was found to be a constructive trustee and in breach of his duty to maximize the trust estate. A decedent's residuary estate (after liquidation) was deposited into the solicitor's trust account where it earned no interest. The solicitor was held to be a constructive trustee in the nature of a trustee de son tort because he received the trust funds with knowledge of their character and was a party to the breach of trust by the executor-trustee. The breach of trust was the failure to invest the trust funds. In his analysis, the trial Judge did not advert to the law of unjust enrichment. This omission was reasonable as the defendant solicitor had clearly not been enriched. There existed only a deprivation suffered by the plaintiff beneficiaries of the decedent's estate resulting from the failure to invest.

To follow up on Professor McClean's second point, though not all cases in which improper profits are earned by fiduciaries can be viewed as giving rise to an unjust enrichment constructive trust, in some instances this is possible. In Lake Mechanical Systems Corporation v. Crandell Mechanical Systems Incorporated, ${ }^{43}$ Locke J. concluded that a business advantage appropriated by senior officers of an organization in breach of their fidiciary duty, did attract the law of unjust enrichment. Locke J. did not impose a constructive trust but concluded that in assessing damages he was not limited to the "classical rules" of the older personal forms of action such as conversion, detinue and trover but could make an award under the more flexible principles of unjust enrichment. ${ }^{44}$ Though not an authority for the proposition that profits generated by breach of fidiciary duty may be the subject matter of a remedial constructive trust, the Lake Mechanical case opens the door to this possibility by concluding that such profits are caught under the umbrella of unjust enrichment.

By contrast, in Syncrude Canada Limited v. Hunter Engineering Company Inc. ${ }^{45}$ the British Columbia Court of Appeal imposed restitutionary constructive trusteeship on Syncrude Limited precisely in respect to such profits. In that case a Canadian company (C.Co.) fraudulently misrepresented itself as a subsidiary of an American company (A.Co.) who had had previous business dealings with Syncrude. As a result, C.Co. was able to obtain contracts for the sale of gearboxes to Syncrude. Syncrude became aware of the claim of A.Co. to the benefits of the contract of sale between itself and C.Co., and established a trust fund into which it paid the contract price. The trust provided that the interest generated by the trust fund was to be paid to Syncrude and that the entitlement to the capital be determined through a court action. Subsequently, A.Co. successfully sued C.Co. and it was held that upon assuming the contractual warranty and service obligation of C.Co., A.Co. was entitled to the benefit of the trust fund. The requirement that A.Co. undertake C.Co's warranty obligations, should a court rule in its favour, was specificially provided for in the trust. The trust funds represented C.Co's profit from the sale transaction.

42. (1987) 26 E.T.R. 1 (B.C.S.C.).

43. (1985) 9 C.C.E.L. 52 (B.C.S.C.).

44. Id. at 57.

45. (1985) 68 B.C.L.R. 367 (B.C.C.A.). 
At first instance, in an action brought by Syncrude against A.Co., it was held that A.Co's entitlement to the trust fund was based solely on the provisions of the trust agreement. Accordingly, A.Co. could not claim any entitlement to any of the interest generated by the trust fund. The argument that A.Co. was entitled to the fund because of the doctrine of constructive trust arising from unjust enrichment was rejected. It was also held that there was no fiduciary relationship between Syncrude and A.Co. On appeal, it was concluded that the trial Judge erred in finding that the law of unjust enrichment could not sustain the claim of A.Co. No reference was made to the traditional institutional constructive trust which might have been imposed on Syncrude on the basis that it had established the trust fund with full knowledge that the purchase monies which formed the fund were the subject matter of a fiduciary claim. In principle, Syncrude was in the same position as any person who acquires property with the knowledge that it is subject to a trust claim. This case demonstrates that there is some overlap between the unjust enrichment constructive trust and the institutional constructive trust which is imposed on persons who come into possession of funds generated by breach of fiduciary duty.

Therefore, whether any given case is appropriately analyzed on the basis of the traditional constructive trust or the constructive trust arising from unjust enrichment, or both, will depend upon the facts of that particular case. In some cases, such as MacMillan Bloedel, the profits appropriated by a fiduciary in breach of his or her duty cannot be said to give rise to an unjust enrichment; whereas in other cases, such as Syncrude Canada, unjust enrichment is an appropriate basis for analysis, though perhaps not the exclusive basis. It follows that lawyers must continue to be familiar with the English form of constructive trust, as well as the unjust enrichment and, perhaps, good conscience versions of such trusts.

\section{THE CONCEPTS OF DEPRIVATION AND ENRICHMENT}

An examination of the cases suggests that the conceptual elements of enrichment and deprivation in a case of unjust enrichment should be thought of in the most expansive of terms.

\section{A. DEPRIVATION}

\section{The General Concept}

Deprivation refers to any loss of money or money's worth that takes the form of a contribution. The phrase "money's worth" encompasses property, services or valuable rights such as choses in action. Numerous cases have held that contributions of money towards the payment of household expenses, ${ }^{45}$ the provision of domestic and housekeeping serv-

46. Schumacher v. Schumacher (1984) 56 B.C.L.R. 381, 17 E.T.R. 110, 40 R.F.L. (2d) 153 (C.A.). 
ices, ${ }^{47}$ the provision of labour for a farm ${ }^{48}$ or other business ${ }^{49}$ or even the construction of a home, ${ }^{30}$ are all contributions which give rise to a deprivation. It seems that any contribution that leaves a person with less than he or she had prior to the contribution or, in the case of services, less than that person would have had if they were compensated for their services is a deprivation. Canadian courts have expressly recognized that

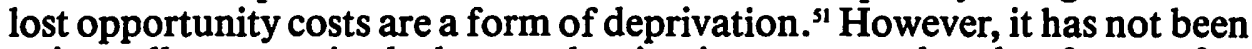
universally recognized that a deprivation must take the form of a contribution. A deprivation which is not also a contribution cannot found an action for unjust enrichment because it cannot give rise to an enrichment. Accordingly, Cohen J., in the case of Bracken v. Konduc Estate, ${ }^{32}$ erred in concluding that the plaintiff had suffered a deprivation as a result of contracting herpes from the defendant, ${ }^{53}$ and having her health deteriorate by worrying about him. Similarly, Trainor J., in the case of Rosenfeldt $\mathrm{v}$. Olson, ${ }^{54}$ erred in concluding that the loss of children murdered by the infamous mass killer, Clifford Olson, was a deprivation.ss Finally, because the concept of deprivation necessarily entails a contribution, the existence of deprivation ensures the presence of enrichment. ${ }^{36}$

\section{Deprivation of Money and Property}

Where money is contributed directly to the acquisition of an asset in another's name, or property is gratuitously transferred to another, traditional analysis suggests that this gives rise to a presumption of resulting trust. ${ }^{57}$ There is no reason why such contributions could not be considered under the law of unjust enrichment to be forms of deprivation. As noted previously, ${ }^{58}$ trust concepts which pre-date the development of the

47. Sorochan v. Sorochan (1985) 36 Alta. L.R. (2d) 119, 44 R.F.L. (2d) 144 (C.A.); revd (1986) 29 D.L.R. (4th) 1, 2 R.F.L. (3d) 225 (S.C.C.).

48. Id.

49. Olerenshaw v. Rasmussen (1982) 42 B.C.L.R. 109 (S.C.).

50. Yuschyshyn v. Florkow (1984) 16 E.T.R. 250 (B.C.C.A.).

51. See Wilson v. Munroe (1983) 13 E.T.R. 174 (B.C.S.C.) per McKenzie J. at $182-183$ and the cases cited therein. Of course the nature of the opportunity that is lost is variable. Obviously there is a loss of opportunity to provide similar services to others for remuneration. As well, there may be a loss of opportunity to realize on professional or skill training or the lost opportunity to acquire a professional or technical accreditation. However, since restitution requires the return of enrichment and is not concerned with compensating the deprived party for the value of his or her deprivation, it is unnecessary to pinpoint the precise nature of the lost opportunity.

52. Unreported, September 8, 1987, (Vancouver C853089), digested 721 [1988] W.D.F.L. March 15, 1988 (B.C.S.C.).

53. The suit was actually brought against the estate of the deceased co-habitant.

54. (1984) 20 E.T.R. 133 (B.C.S.C.); revd (1985) 22 E.T.R. 83 (B.C.C.A.); leave to appeal to S.C.C. denied.

55. Id. 20 E.T.R. at 157.

56. However, it will still be necessary to establish that the defendant was the person enriched by the plaintiff's contribution and that the enrichment was proximately linked to the contribution.

57. Supra, n. 5, 299.

58. See the text at $417-418$. 
doctrine of unjust enrichment have been recognized, in some cases, to overlap with the remedial constructive trust emanating from the doctrine of unjust enrichment. It follows that, in substance, as long as a contribution gives rise to a deprivation, it should be treated as such. Merely because equity has provided a traditional remedy for these forms of contributions does not alter the fact that when a person contributes money to the acquisition of an asset or transfers an asset, that person has less money or money's worth.

\section{Intangible Contributions}

Will any form of contribution to a relationship be considered to be a deprivation? In Davidson v. Worthing ${ }^{99}$ McEachern C.J. stated that " $[t]$ he differential intangible contributions each [party] made to the other are incapable of being settled as on an accounting." ${ }^{60}$ The context of this gratuitous statement does not provide much guidance as to its intended meaning. The statement is made immediately after a reference to the testimony of the defendant in the action that the plaintiff was "his 'helpmate, a wife in every sense except legally' and 'she looked after the home' " ${ }^{61}$ Possibly McEachern C.J. was referring to restitutionary claims based upon general contributions to a relationship such as being a "good spouse". Or the statement may mean that when a contribution does not have a readily quanitifiable economic value it makes good sense to exclude the value of such contribution on an accounting. The problem with this approach is that today courts seem to be prepared to place a value on virtually anything. If one breaks down the factors which give rise to someone being a good spouse it may well be that these factors can be given a reasonably objective economic value. But what about a contribution of love and affection? Can such a contribution be given a monetary value which is not totally speculative? Valuing love and affection may be no more and no less speculative than assessing for tort law purposes the losses of a person who has experienced pain and suffering and diminished enjoyment of life. For the law of unjust enrichment, the difficulty associated with assessing the value of a particular contribution should not affect its characterization as a deprivation any more than in tort law the difficulty of assessing the value of a loss should affect its characterization as a compensatable loss.

How then can we make sense of McEachern C.J's statement? It is suggested that he is simply stating that not all contributions to a relationship should as a matter of juristic policy give rise to restitution. In particular, intangible contributions such as the provision of love and affection will not found a restitutionary action because the parties do not, and should not, expect to benefit from these sorts of contributions. Though the law of unjust enrichment has contributed to the blurring of the line separating interpersonal relationships and economic unions, contributions to a relationship in the form of love and affection clearly belong in the

59. (1987) 26 E.T.R. 60 (B.C.S.C.).

60. Id. at 66 [emphasis added].

61. Id. 
former category. Moreover, compensating people for contributions of love and affection would undermine the dignity of human relationships. Therefore, intangible contributions can be viewed as deprivations, but deprivations which will not give rise to restitution because there is a juristic justification for refusing relief.

\section{Interceptive Subtraction}

In most cases, contributions which give rise to restitutionary actions emanate directly from the plaintiff in the action. That is, unjust enrichment involves two parties; the contributor and the party enriched. However, occasionally the benefit acquired by the enriched party emanates from a third person. For example, if A misdelivers cash to which B is entitled and gives it to C, B is still deprived notwithstanding that he did not directly contribute the monies to C. Instances such as these have been referred to by Birks as cases of "interceptive subtraction". ${ }^{62}$

Interceptive subtraction is a form of deprivation because the deprived party is less well off than he or she would have been had the interception not taken place. Birks suggests that interceptive subtraction only exists if the wealth in question "would certainly have arrived in the Plaintiff" had the interception not occurred.$^{63}$ If the plaintiff only had a small chance of obtaining the benefit or no chance he concludes that interceptive subtraction does not exist; ${ }^{64}$ though he observes that occasionally courts, without scrutiny, simply presume that a benefit would undoubtedly have been obtained by the plaintiff. ${ }^{65}$ Accordingly, Birks would not categorize classic cases such as Keech v. Sanford ${ }^{66}$ and Boardman v. Phipps ${ }^{67}$ as cases of unjust enrichment. ${ }^{68}$ In both cases the benefit acquired by the defendant trustees could not be said to be destined for the trust beneficiaries. At best, in both cases, the chances of the trust beneficiaries acquiring the benefits that were obtained by their trustees were small. These cases, in Birks view, are properly solved by the institutional constructive trust which attaches itself to profits obtained by fiduciaries arising from a conflict of interest. ${ }^{69}$

The language utilized by Birks in developing the concept of interceptive subtraction suggests that the interception of a probable, as opposed to a certain, benefit cannot trigger an unjust enrichment claim. Birks states that the success of a claim involving interceptive subtraction depends on the

62. Supra, n. 23 at 133.

63. Id.

64. Id. at 133-138.

65. Id. at 137.

66. (1726) 2 Eq. Cas. Abr. 741, 25 E.R. 223 (Ch.D.).

67. [1967] 2 A.C. 46, [1966] 3 All E.R. 721 (H.L.).

68. Supra, n. 23 at 340-341 where Birks makes this point in respect to the Boardman v. Phipps case.

69. It will be recalled that in the MacMillan Bloedel case, supra, n. 38, the British Columbia Supreme Court concluded that a secret profit made by the managers of the plaintiff company whose policy precluded it from receiving the profits could not be viewed as a deprivation which would attract the doctrine of unjust enrichment. The liability of the defendants in that case was placed squarely on a traditional constructive trust basis. 
ability of a plaintiff to prove "that the wealth would certainly have accrued to"70 or was "destined for" " or "indubitably en route to" the plaintiff. He asserts that the interceptive subtraction concept is not artificial because: ${ }^{73}$

The certainty that the plaintiff would have obtained the wealth in question does genuinely indicate he became poorer by the sum in which the defendant was enriched.

It is difficult to understand why certainty of benefit is a necessary element of a claim based upon interceptive subtraction. The substantive necessity of establishing that a plaintiff has been deprived - of wealth which would have gone to him or her - should be distinguished from the evidentiary question of what burden of proof must be satisfied in establishing the deprivation. Basic principles of civil litigation suggest that if a plaintiff can demonstrate that the defendant has intercepted wealth which probably would have been acquired by the plaintiff, then deprivation has been proven. Why should the plaintiff's burden of proof be greater than the usual "balance of probabilities"?

Obviously, the scope for claims based on unjust enrichment is considerably broadened if interceptive subtraction can be based upon the probability (rather than certainty) that the plaintiff would have acquired the wealth in the hands of the defendant. Such a theory would introduce the spectre of unjust enrichment analysis in unexpected, though not inappropriate, contexts. For example, the recent rather high profile case of International Corona Ltd. v. Lac Minerals Ltd. ${ }^{74}$ could well - if the probability theory is correct - have been analyzed in unjust enrichment terms. In this case two mining companies, Corona and Lac, were negotiating a joint exploitation agreement of a gold field owned by Corona. Lac acquired an adjoining property, rich with gold, even though it was aware that Corona was actively pursuing the acquisition of that very property. In part Lac's motivation to acquire the property was based on confidential information transmitted to it by Corona during negotiations respecting the Corona property. In these circumstances the trial Judge, whose decision was affirmed by the Court of Appeal, concluded that Lac held the property it had acquired (subject to certain terms and conditions) as constructive trustee for Corona. Lac had breached both its fiduciary duty and duty of confidence in acquiring the property. The thrust of Lac's vigorous defence in the action was that it was a business competitor dealing with Corona at arm's length and, therefore, should not be relegated to the role of guardian of Corona's interests. In the particular circumstances of this case the assertion was not persuasive, but even if the assertion had succeeded in negating both the fiduciary duty and confidential relationship between the parties, it is suggested that Lac might nevertheless have been liable on the theory of unjust enrichment. Holland J., at trial, and this point was emphasized on appeal, found that the

70. Supra, n. 23 at 133.

71. Id. at 135.

72. Id. at 136 .

73. Id. at 134.

74. (1986) 25 D.L.R. (4th) 504 (Ont. S.C.); affd (1987) 62 O.R. (2d) 1 (Ont. C.A.), leave to appeal to S.C.C. granted. 
plaintiff, Corona, in all probability, but for the actions of Lac, would have been able to purchase the gold-rich disputed lands."

Though no Canadian case has expressly utilized the concept of interceptive subtraction, at least three other reported cases can also be cast in these terms. In Yorkshire Trust Company v. Empire Acceptance Corporation $L t d .{ }^{76}$ investors in a particular mortgage were held to have priority over the general creditors of a mortgage brokerage house, E. Ltd., with respect to a damage award obtained by the receiver/managers of E. Ltd., for the negligent appraisal of mortgaged property. The practice of E. Ltd. was to finance mortgages and assign them to particular investors. It would administer the mortgage and earn a profit by paying its investor a lower rate of interest than that paid by the mortgagor. A second mortgage obtained by E. Ltd., and assigned to the plaintiffs, was based upon a negligent appraisal of the mortgagor's equity in the mortgaged property. In fact, upon default and foreclosure of the mortgage there was no equity to which the second mortgagee's security interest could attach. Subsequently, E. Ltd. experienced financial difficulties and receiver/managers were appointed. They sued the appraiser and recovered approximately $\$ 360,000.00$. The question was whether these monies (and interest thereon) should be distributed amongst E. Ltd's general creditors or exclusively to the plaintiffs. The party litigants agreed that had the monies been realized upon foreclosure they would have been payable to the plaintiffs and not, since E. Ltd's assets were unpooled, the general creditors. After rejecting the assertion that the receivers for E. Ltd. held the damage award as agent for the plaintiffs, the Court considered whether the receiver held the fund for the plaintiff as constructive trustee. In so doing, the Court engaged in conventional unjust enrichment analysis. The most difficult point was whether the investors had suffered a detriment. The Court concluded that they had and in so doing undertook a tort law analysis to demonstrate that the investors had a cause of action against the appraisers which they were deprived of as a result of the successful law suit brought by the receivers. It was then observed that if the investors were to be deprived of the proceeds of the law suit, "they will indeed have suffered a detriment". " This case can be analyzed on the theory of interceptive subtraction, or perhaps more sensibly, it can be viewed as a case in which the Court recognized that appropriating the benefit of the plaintiffs' chose in action was a form of deprivation. This point highlights a distracting aspect of Birks' concept of interceptive subtraction. It keys on the process of deprivation rather than describing its subject matter. The characterization of the subject matter of a deprivation is indispensible to determining whether a particular plaintiff

75. Id. O.R. at 61. Hence, if the probability theory of interceptive subtraction is correct, the elements of enrichment, deprivation and causal connection would be established and the ultimate success of Corona would depend on the Court's assessment of the crucial element of juristic justification for and against retention of the benefit. Without fully analyzing this point, it should suffice to note that even absent a confidential or fiduciary relationship the trial Court's finding, that it was a custom in the mining industry that companies involved in serious negotiations regarding joint ventures not act to the detriment of each other, could tip the balance in favour of the plaintiff.

76. Supra, n. 35.

77. Id. at 105. 
has suffered a loss. The process by which this deprivation occurs is really quite irrelevant to ascertaining whether the plaintiff has been deprived.

In Kimwood Enterprises Ltd. v. Roynat Inc. ${ }^{78}$ the Manitoba Court of Appeal held that a tax rebate cheque sent in "error" by Revenue Canada to the "wrong" company was unavailable to the secured creditors of that company, notwithstanding that these creditors had registered their security interests under the Personal Property Security Act. The Court held, citing Pettkus v. Becker as authority, that any other result would give rise to unjust enrichment of the secured creditors. The deprivation in this case can be viewed in terms of interceptive subtraction. However, it is suggested that the plaintiff's deprivation is best viewed in terms of it losing its property. In equity the rebate cheque from the date of its issue belonged to the plaintiff company. ${ }^{79}$

In Rosenfeldt v. Olsen, ${ }^{80}$ the British Columbia Court of Appeal employed the interceptive subtraction analysis, without referring to it as such, to conclude that the plaintiffs had not been deprived of the assets which they sought in their action. It will be recalled that Olsen killed several children and agreed to give the R.C.M.P. information about the whereabouts of their bodies in exchange for its promise to establish a trust fund in favour of Olsen's immediate family. A trust fund of $\$ 100,000.00$ was established and an action was subsequently brought by the parents of the victims alleging, inter alia, that the law of unjust enrichment warranted the conclusion that these funds were being held on constructive trust for them. The trial Judge, Trainor J., found a deprivation in the form of the loss of the children and quantified this loss using as a barometer the successful action for damages under the Family Compensation Act brought by the parents against Olsen. He also concluded that there had been an enrichment (receipt by Olsen of the trust funds) and that there was no juristic reason to allow Olsen to retain this benefit. Trainor J's judgment is fraught with problems, however, and the Court of Appeal overturned his decision on the simple basis that the claimants had not been deprived of the trust funds. On behalf of the Court of Appeal, Hinkson J.A. concluded:81

The payment to [the trustee] McNeney did not deprive the plaintiffs of money which, if it had not been paid to McNeney, would properly have been payable to the plaintiffs. Thus, the payment to McNeney did not result in any corresponding deprivation of the plaintiffs.

In other words there was no interceptive subtraction of benefits or property destined for or likely to enure to the plaintiffs. ${ }^{82}$

78. (1985) 15 D.L.R. (4th) 751 (Man. C.A.).

79. Only title belonged to the named payee.

80. Supra, n. 54.

81. Id. at 89.

82. As an aside, it is unfortunate that Hinkson J.A. collapses together the constituent elements of deprivation and causal connection. His comments can be interpreted to mean that there was no causal connection between the plaintiffs' deprivation and the defendants' enrichment. If the loss of the children can properly be characterized as a deprivation and the award under the Family Compensation Act as a quantification thereof, then it is clear that an alternate reason for the judgment could have been that this loss was not linked with sufficient proximity to the defendants' gain to be considered to be causally connected. This point will be addressed later in the text. In the developmental period of the law of unjust enrichment it would be of great value if the judiciary were to discuss the constituent elements of unjust enrichment separately. 


\section{B. ENRICHMENT}

The concept of enrichment is also extremely broad. Pettkus v. Becker concluded that $A$ is enriched if $B$ contributes to the acquisition of assets in A's name. Subsequent cases, including the Alberta Court of Appeal's decision in Sorochan v. Sorochan ${ }^{83}$ and the Newfoundland case of Dawson v. Toll ${ }^{\text {s4 }}$ extended the notion of enrichment to include cases where contributions have enhanced the value of property. The Supreme Court of Canada's decision in Sorochan makes it clear, however, that even this expanded notion of enrichment is far too narrow. After acknowledging that "improvement" of property is a form of enrichment, the Court went on to conclude that so too is "preservation" or "maintenance". ${ }^{85}$ The Court also concluded that savings derived from the unremunerated provision of domestic and farm labour is also an enrichment.$^{86}$ Earlier cases had recognized that the liberation of A's money through the provision by B of free labour to a business, ${ }^{87}$ or a property improvement project, ${ }^{88}$ or the unremunerated provision by $B$ of domestic and farm labour, ${ }^{89}$ were forms of enrichment. Equally, other cases had recognized that the liberation of A's money by B making financial contributions to expenses of a household, ${ }^{, 0}$ or the provision by B of prudent financial management skills, ${ }^{91}$ were enrichments. The Sorochan case added to the catalogue of forms of enrichment by holding that contributions which prevent property divestment can be considered to enrich the property owner. ${ }^{92}$ Presumably, therefore, if B paid A's municipal property taxes, A would be considered to have been enriched on the theory that otherwise the property might have been seized and sold at a tax sale. In sum, it would seem that a person is enriched if that person is in a better financial or proprietary position than he or she would have been in had the contribution not been made. It follows, and it has so been held, that the reduction of another's debt enriches the debtor. ${ }^{93}$

The decision in Novick Estate v. Lachuk Estate ${ }^{24}$ suggests that the breadth of the concept of enrichment may still not yet be fully appreciated.

83. Supra, n. 47 .

84. (1983) 43 Nfld. \& P.E.I.R. 98,127 A.P.R. 98 (Nfld. S.C.).

85. Supra, n. 47, R.F.L. at 234.

86. Id. at 235.

87. See, for example, Olerenshaw v. Rasmussen, supra, n. 49.

88. See Brown v. Brown (1983) 45 A.R. 368 (Alta. Q.B.), Eckert v. Schafer (1985) 45 R.F.L. (2d) 330 (Sask. Q.B.) and Rochon v. Emary (1981) 26 B.C.L.R. 119, 21 R.F.L. (2d) 366 (S.C.); affd (1982) 32 R.F.L. (2d) 217 (C.A.).

89. See Schumacherv. Schumacher, supra, n. 46 and Herman v. Smith (1984) 42 R.F.L. (2d) 154, 34 Alta. L.R. (2d) 90, 18 E.T.R. 169 (alta. Q.B.), with respect to money liberated through contribution of domestic services and Pettkus v. Becker, supra, n. 1 , in relation to contribution of farm labour.

90. See, for example, Murray v. Roty (1983) 147 D.L.R. (3d) 438, 41 O.R. (2d) 705, 34 R.F.L. (2d) 404 (C.A.).

91. Schupback v. Rambo (1981) 26 B.C.L.R. 154 (S.C.).

92. Supra, n. 47 , R.F.L. at 240.

93. Rosenfeldt v. Olson, supra, n. 54, 20 E.T.R. at 157.

94. Supra, n. 30. 
Mrs. Novick during the last ten years of her life had contributed financially to the support of Mr. Lachuk and to their household. After her death her estate sued Mr. Lachuk (and after his death his estate) on the theory of unjust enrichment. The action failed because, inter alia, it was held that Novick did not contribute to the acquisition or improvement of property brought into the relationship by Lachuk. On the question of whether Novick had contributed to the maintenance of the assets the Court noted that "the property ...., during the time [Lachuk] ... and Novick lived and cohabited together, may have deteriorated". ${ }^{95}$ It is suggested that this is not conclusive of the absence of an enrichment. If the level of deterioration would have been worse without Novick's contribution than it was with that contribution, the Court should have found that Lachuk, and therefore his estate, had been enriched. Again, enrichment occurs if a person has more than he or she would otherwise have had in the absence of the contribution of the complainant. On the facts of Novick v. Lachuk it would seem at least plausible to suggest that the property in question might have deteriorated, in the absence of Novick's contribution, to an even greater extent than it actually did. The judgment does not discuss who paid property taxes, but it would seem reasonable to infer that it was Novick. During the last five years of her life Novick provided almost all of the financial support for the household. Her contributions might well have resulted in the retention of the property by Lachuk. Indeed Lachuk's financial situation was so marginal that in the absence of Novick's contribution he might well have had to sell the property to cover his basic living expenses.

\section{v. CAUSAL CONNECTION}

\section{A. THE ERROR OF REQUIRING A CONNECTION BETWEEN THE PLAINTIFF'S CONTRIBUTION AND THE DEFENDANT'S PROPERTY}

In Pettkus v. Becker, Dickson C.J. concluded that the connection between deprivation and enrichment must be "substantial and direct",, and that this was an "issue of fact". ${ }^{97}$ The requirement that a contribution be substantial, it is suggested, is merely a statement of the de minimis principle. The requirement of directness, on the other hand, seems to be a requirement of causal proximity. In numerous unjust enrichment cases decided since Pettkus v. Becker the courts have taken the view that the connection between a claimant's contribution and the defendant's acquisition, retention or maintenance of a particular asset may be indirect. For

95. Id. at 224.

96. Supra, n. 1, S.C.R. at 852.

97. Id. 
example, in Murray v. Roty, Cory J. stated: ${ }^{98}$

In relationships such as this the contributions of one of the parties towards the acquisition of assets will frequently be indirect. This will arise from the very nature of a mutual effort. The fact that one party buys all of the groceries which permits the other to make the direct payment towards a property acquisition should not deprive the grocery buyer of all legal interest in the property. An indirect contribution towards the acquisition of property should be just as readily recognized as the one that is direct. The amount of contributions by the parties may well vary. The disproportionate contribution should not operate as a bar to the recognition of the interest of the small contributor. Rather, it may in some circumstances be reflected in the size of the interest awarded a party.

It is important to note that although a contribution may be indirectly related to the acquisition of a particular asset, it may nevertheless be directly related to the enrichment of a party. If A purchases groceries with her own funds, this liberates the funds of her spouse to be utilized for other purposes. The spouse is enriched even prior to the use of the funds for these other purposes. This enrichment is direct because it occurs at the same instant as, and because of, the expenditure. Since the concept of enrichment includes liberated money, there will always be a direct causal link connecting the plaintiff's deprivation with the defendant's enrichment if the form of deprivation is a contribution toward the expenses, burdens or projects of the parties or that of the defendant. In these circumstances enrichment in the form of the defendant's savings is inextricably and directly linked to the plaintiff's contributions. Therefore, it should follow that tracing a contribution to a particular asset is not a pre-condition to the success of an unjust enrichment action. Tracing is relevant in determining whether the appropriate remedy for unjust enrichment should be proprietary or personal. However, insisting that a contribution manifest itself in property is erroneous. It amounts to equating unjust enrichment with constructive trust. It should always be remembered that though the restitutionary constructive trust is a remedy for the substantive wrong of unjust enrichment, this wrong may exist in cases where the remedy is inappropriate or unavailable. In these circumstances the simple solution is to provide relief in the form of damages. There are at least two recently reported cases which seem to have fallen into the trap of equating unjust enrichment with the constructive trust and thereby, at least arguably, denied relief when it should have been provided.

In Davidson v. Worthing, previously discussed, ${ }^{99}$ McEachern C.J., after concluding that all elements of unjust enrichment existed, stated that: ${ }^{100}$

If that were all there were to it I would have no hesitation in saying that on such basis Miss Davidson should recover a small award of cash or property from Mr. Worthing who has been left with substantially more out of the relationship than she has.

98. Supra, n. 90 , D.L.R. at 444 .

99. See text at $420-421$.

100. Supra, n. 59 at 67. 
He then went on to quote from the following passage from Sorochan: ${ }^{101}$

These cases reveal the need to retain flexibility in applying the constructive trust. In my view the constructive trust remedy should not be confined to cases involving property acquisition. While it is important to require that some nexus exist between the claimant's deprivation and the property in question, the link need not always take the form of a contribution to the actual acquisition of the property. A contribution relating to the preservation, maintenance or improvement of the property may also suffice. What remains primary is whether or not the services rendered have a "clear proprietary relationship"..., to use Professor McLeod's phrase. When such a connection is present, proprietary relief may be appropriate. Such an approach will help to ensure equitable and fair relief in the myriad of familial circumstances and situations where unjust enrichment occurs... [McEachern C.J's emphasis]

No doubt the emphasized portions suggest that there is a requirement of causal connection between contribution and property. However, it is crucial to note that this statement in Sorochan is included in a part of Dickson C.J.s judgment entitled "Constructive Trust". ${ }^{102}$ That part is exclusively concerned with deciding whether damages or the restitutionary proprietary remedy of constructive trust (or some combination of both) is the appropriate remedy to correct the unjust enrichment of Alex Sorochan. The question of appropriate remedy was discussed by the Chief Justice only after he had concluded that the requirements for unjust enrichment had been satisfied. ${ }^{103}$ The only remaining issue was which remedy should be invoked to remedy the enrichment. Therefore, the fact that Miss Davidson was unable to establish a sufficient connection between her domestic services and the log home over which she sought a proprietary interest, should not have precluded here from obtaining damages. Unfortunately it did. ${ }^{104}$ On the other hand, it may well be that there were other circumstances in the case which justified the failure of her action. ${ }^{105}$

The melding together of unjust enrichment and constructive trust may also explain the unfortunate results in the Nova Scotia case of Cleveland $v$. Gillis Estate.$^{106}$ Frances Cleveland had been raised by her aunt and uncle but they did not formally adopt her. She was a devoted "daughter" who did most of the housework and shopping for her "parents" while she lived with them. Some time after her marriage, Frances left her aunt and uncle's home but subsequently moved back, along with her husband and child, when she and her husband experienced financial difficulties. During the ensuing five year period, while living in her aunt and uncle's home, she and her husband purchased food for the entire household. In addition to contributing domestic services she assisted in her uncle's taxi business as a telephone receptionist and dispatcher. She did this every day for six years, seven hours a day. The aunt became ill and for thirteen years Frances

101. Supra, n. 47, R.F.L. at 239.

102. Id. at 236.

103. Id.

104. See Davidson v. Worthing, supra, n. 59, at 67-68 where McEachern C.J. states that "[h]owever valuable the services of Miss Davidson may have been in human terms, I do not think it can be said that she has established a sufficient connection between those services (her deprivation) and the log home which is sought to be the subject matter of the trust:"

105. See infra, text at 441 .

106. Supra, n. 30 . 
provided her with special care. The uncle also required special care for six months prior to his move to a nursing home and this included cleaning up after him "when he messed the bed". ${ }^{107}$ The claimant did receive some benefits from her continuing relationship with her aunt and uncle, for example, she lived with them rent-free, yet by comparison, her contribution to them seemed far more substantial. Unfortunately, the aunt and uncle both died intestate despite, on several occasions, assuring the complainant that she had been left their estates in their wills.

An action against the estate claiming a sum of $\$ 85,000.00$ was disallowed by the registrar of the Court of Probate. The appeal, heard by Palmeter, the Chief Justice of the County Court, was disallowed. The manner in which he resolved the issues in the case is instructive. The court outlined four bases on which the claim could be founded: (i) quantum meruit; (ii) unjust enrichment; (iii) resulting trust; and (iv) constructive trust. As to quantum meruit, Palmeter C.J. held that though the complainant might have expected some benefit from the estate, her motivation for providing the services was love and affection; there was no evidence that her services were performed on the promise, express or implied, of acquiring benefits. In respect to the issue of unjust enrichment, it was concluded that he would defer discussion of the issue until his consideration of the constructive trust issue. He justified this approach by stating that the "doctrine of unjust enrichment is not an issue to stand alone as a possible ground for appeal". ${ }^{108}$ On the issue of resulting trust it was concluded that there was no common intention warranting the imposition of a resulting trust. Finally, the constructive trust argument was rejected because there was "[no] direct causal connection between the deceased's property and the work done by the appellant in the home for the deceased." ${ }^{109}$ It can readily be seen that the melding together of the remedial and substantive aspects of the law of unjust enrichment can and did give rise to the wrong results. Frances Cleveland should have received a substantial monetary award because her aunt and uncle's estates were substantially enriched at her expense.

\section{B. PROXIMATE CAUSE}

Though it is enrichment per se and not proprietary enrichment that needs to be established in an unjust enrichment action, the enrichment must be linked "directly" to the plaintiff's deprivation. In the interceptive subtraction cases involving third parties, deprivation and enrichment are inextricably linked to one another and created by an error of a third party who, in the usual case, has sent monies to the wrong party. It has also been suggested above that in the matrimonial property cases, whether a deprivation takes the form of a contribution of money, labour or services, the requirement of directness will always be satisfied. Even if the contribution does not directly make its way into a particular asset of the defendant, any liberation of the defendant's assets ensures that the direct

107. Id. at 407.

108. Id. at 410 .

109. Id. at 411 . 
causal link requirement will be satisfied. However, in a non-matrimonial context the requirement of a "direct causal connection" can be a real hurdle, as it is in other areas of law. Both criminal and tort law require some degree of proximity between the conduct of a wrongdoer and the injury of a victim. "Attributive", "legal" or "proximate" cause, unlike factual causation, cannot be measured, detected or proved in an objective manner by scientific means. The reality is that causation in law is a somewhat metaphysical concept which requires that a judgment be made about the proximity of the plaintiff's "injuries" and the defendant's misconduct or gain. There is no reason to believe that the causation element of unjust enrichment will escape this metaphysical arena and, indeed, it may well be that the proximate cause notion of tort law effectively serves the needs of the law of unjust enrichment. Heretofore, the cases have not provided any real guidance as to the nature of the necessary causal link between enrichment and deprivation; most merely indicate that this link must be direct. However, in at least two reported non-matrimonial cases, the link between deprivation and enrichment was insufficient to satisfy any reasonable test of legal causation.

One of the cases, $R e$ Northern Union Insurance Co. ${ }^{110}$ dealt with the claim of B.C. Hydro against the bankrupt estate of its insurer, Northern Union Insurance Company. B.C. Hydro claimed to be a beneficiary of a constructive trust in respect of a portion of the estate, entitling it to priority over Northern's creditors. B.C. Hydro had insured its property for losses of up to 19.3 million dollars. In order to protect itself against its rather substantial potential liability to B.C. Hydro, Northern acquired liability insurance in respect to its obligation to B.C. Hydro. This form of liability insurance is common in the insurance industry and is acquired through the medium of reinsurance contracts. These contracts are entered into in order to spread the risk of the original insurer to several insurers. In fact, B.C. Hydro sustained a loss of approximately $\$ 3.5$ million. One million dollars was paid by Northern to the insured, but before the remaining amount was paid, Northern was declared to be insolvent. Three reinsurers set aside the monies owed by them to Northern and an application was brought by the insured to determine whether it had priority to the reinsurance monies over Northern's general creditors. At trial, Kroft J. held that none of the requirements of constructive trust were present. As to causal connection, it was found that the mere fact that Northern or the liquidator recovered under the policies of reinsurance "is not an enrichment that has any causal connection with B.C. Hydro"."' This is surely correct. Northern, in reinsuring against its liability, was not insuring as agent or trustee for B.C. Hydro and, accordingly, B.C. Hydro's loss was caused directly by the insolvency of Northern. The enrichment of Northern's liquidator and, therefore, its general creditors occurred because of the contracts of

110. [1985] 2 W.W.R. 751, 55 C.B.R. (N.S.) 126, [1985] I.L.R. 1-1899, 33 Man. R. (2d) 81 (Man. Q.B.); affd (sub nom. British Columbia Hydro and Power Authority United Power Limited v. Dunwoodie Ltd.) [1986] 1 W.W.R. 476 (Man. Q.B.A.D.).

111. Id. W.W.R. at 764. Without specifically addressing the causal connection issue, the Manitoba Court of Appeal simply affirmed Kroft J's judgment on the question of unjust enrichment. 
reinsurance entered into by Northern and not directly because of B.C. Hydro's loss. In short, though B.C. Hydro's property loss may have been the sine qua non of the liquidator's enrichment, it was not the proximate cause. Direct causal connection, as with proximate cause in tort law, cannot be said to exist simply because the "but for" test is satisfied. Undoubtedly, but for B.C. Hydro's loss the liquidator would not have been enriched; however, the connection is still too remote. If Northern had not entered into contracts of reinsurance there would not have been an enrichment and it is these contracts that are the proximate cause of the enrichment.

The case of Rosenfeldt $\mathrm{v}$. Olsen ${ }^{112}$ can also be viewed as having been decided on the basis that the plaintiff's loss was only the sine qua non, but not the direct cause of the defendant's gain. It will be recalled that the Court of Appeal concluded that the Olsen family trustee did not acquire money which, if not paid to him, would have gone to the plaintiffs. Hence it was concluded that the payment to the trustee "did not result in any corresponding deprivation of the plaintiffs".${ }^{13}$ Even if the trial Judge was correct in characterizing the plaintiffs' deprivation as the loss of their children as evaluated by the award made under the Family Compensation Act, ${ }^{114}$ this loss did not lead directly to the enrichment of the defendants. Rather the enrichment is attributable to the contract entered into by the R.C.M.P. and Olsen to create a trust in exchange for Olsen's cooperation in locating the children's bodies. Once again, but for the plaintiff's loss, the defendants would not have been enriched; however, it did not follow that the defendant's gain was causally linked in the legal sense to the plaintiff's losses.

\section{JURISTIC JUSTIFICATION}

\section{A. ONUS OF PROOF}

In Pettkus v. Becker, Dickson C.J. points out that the legal system has never been willing to compensate plaintiffs simply because their actions have benefited others. ${ }^{115}$ Accordingly, the test of unjust enrichment aside from requiring proof of enrichment, deprivation and a causal link between the two, also requires that there be an "absence of any juristic reason for the enrichment". ${ }^{16}$ In Re Northern Union Insurance Co., Kroft J. indicated that the plaintiff bore the burden of demonstrating the absence of juristic justification for the enrichment. ${ }^{117}$ If this is so, how does the plaintiff discharge this burden? Must the plaintiff negative any possible justification for the retention of the benefit actually offered by the defendant or must the plaintiff go further and establish a positive reason why this

112. Supra, n. 54.

113. Id. 22 E.T.R. 89 [emphasis added].

114. See the text at $419-420$ where it is suggested that this characterization is wrong.

115. Supra, n. 1, S.C.R. at 848.

116. Id.

117. Supra, n. 110, W.W.R. at 764-765. 
benefit ought not to be retained. The wording of the test of juristic justification, "absence" of juristic reason for the enrichment, suggests that the burden will be satisfied if the defendant is unable to provide a convincing argument in favour of retention of property. However, the application of the juristic justification test in Pettkus v. Becker suggests that the plaintiff's burden may be more substantial. He or she may have to establish a positive reason justifying the return of the benefit. It will be recalled that on the question of juristic justification, Chief Justice Dickson concluded that it would be unjust to allow the recipient of a benefit in the form of property to retain it where the recipient knows or ought to have known that the contributor of the property reasonably expected to receive an interest in it in return for the contribution. ${ }^{118}$ This is not an absence of a juristic justification for retention of benefit, but rather is a positive reason why this benefit ought not to be retained. This "reasonable expectation of benefit" analysis has been utilized in almost all the quasi-matrimonial property cases decided since Pettkus v. Becker to justify the restitutionary obligation imposed on unsuccessful defendants. It is suggested that in requiring the plaintiff to establish an expectation of benefit, a greater obligation is placed upon the plaintiff than ought to be the case.

Let us assume that $\mathrm{A}$ contributes to the acquisition of assets by $\mathrm{B}$ and that $\mathbf{A}$ has not addressed his or her mind to the question of property ownership or wealth division during the relationship or at its potential termination. This is not an unrealistic scenario, though the increasing sensitivity of the public to proprietary issues undoubtedly makes this scenerio less plausible today than once was the case. The important question is, should spouse A who does not have any expectation of benefit fail in his or her action by virtue of this lack of expectation. No doubt the law should protect reasonable expectation of benefit and, therefore, the plaintiff with this expectation has a stronger case than the plaintiff without this expectation. However, it is suggested that this latter plaintiff has a strong enough case and, therefore, ought to succeed in any event. It should not be forgotten that the defendant has been enriched by the time, effort, money or property of the plaintiff. It is this that makes the retention of benefit by the defendant unjust. If in any given case a plaintiff has a reasonable expectation of benefit this serves only to accentuate the injustice that already exists. Moreover, where an expectation of benefit exists, it is generated by the plaintiff's sense that if he or she has contributed to the defendant's wealth, it would be unfair for the defendant, upon the dissolution of the relationship, to retain the contribution. It is suggested that ordinarily the only difference between the plaintiff who has developed an expectation of benefit and one who has not, is that the former has taken the natural cognitive step of expecting to benefit from the contribution of his or her human capital. It would be unjust to deny relief to the cohabitant who has not taken this cognitive step; it would be placing too much importance on it. Substantive injustice would exist if the defendant was allowed to retain what has been produced by the plaintiff. The expectation of benefit is merely an echo of this injustice. It is

118. Supra, n. 1, S.C.R. at 849. 
suggested, therefore, that once a plaintiff has established enrichment, deprivation and causal connection, a presumptive case of unjust enrichment exists and the burden shifts to the defendant to establish a juristic justification for retention of benefit. The kinds of justifications which might convince a court to allow a defendant to retain a benefit that has been conferred will be discussed below.

Requiring defendants to justify the retention of benefits conferred upon them is not without precedent. If A gratuitously transfers property to B, the presumption of resulting trust arises and the onus is on B to establish either that a gift was intended, ${ }^{19}$ or that there exists some other juristic justification for the retention of the property. For example, B might point to an illegal purpose scheme which motivated $A$ to transfer the property. ${ }^{120}$ If $A$, rather than providing $B$ with a specific asset which is identifiable or traceable, enriches B with services or money which cannot be traced into a particular asset, why should this alter the law in relation to the onus of proof? Property, services and money are all valuable benefits and when a person acquires any of these benefits, in the absence of compelling reasons, the judicial response should be the same. The response should be "why should you be allowed to retain these benefits?" This is not an unfair burden. Notwithstanding the importance of security of interest and the derivative principle that there should be no divesting of property without compelling reasons, socio-economic justice requires restitution. Divestment of property is justified because a compelling reason exists. The property has been generated by the plaintiff.

There are several cases which assume that it is the absence of justification for retention of benefit and not the presence of justification for the restitution of benefit that needs to be established. For example, in Duncan v. Duncan, ${ }^{121}$ Cooke J., in a case in which joint money and effort went into the acquisition of land in the defendant's name, concluded as follows: ${ }^{122}$
A constructive trust exists because the defendant has received more than his share from the joint efforts of the parties. He has the land they have acquired jointly. The deprivation to the plaintiff is obvious. There is no juristic reason why the defendant should have the land free of any claim by the defendant.

Similarly in Murray v. Roty, the Ontario Court of Appeal, in concluding that the defendant was unjustly enriched, stated: ${ }^{123}$

Lastly, it is clear that there is no juristic reason for the enrichment. that is to say Murray

was under no obligation, contractual or otherwise, to provide the work and services for

Roty to the extent that she did.

The suggestion that the onus of finding a justification for retention is on the defendant in an unjust enrichment action is, of course, not meant to preclude a court from finding that there are positive reasons why restitution should be ordered. Indeed, prudent counsel acting for the

119. See Waters, supra, n. 5, at 310-319.

120. Id. at 319-331.

121. (1987) 78 A.R. 171 (Alta. Q.B.).

122. Id. at 174.

123. Supra, n. 90, O.R. at 710 . 
plaintiff should whenever possible, make arguments to this effect. It is conceivable that in a given case there will be arguments for and against retention and a court will have to determine which should prevail. In Yorkshire Trust Co., McLachlin J. concluded that there was both an absence of juristic reason for the retention of benefit by the defendant and a positive reason why the plaintiff should be able to recover the enrichment in question. She stated: ${ }^{124}$

The final element required to establish a constructive trust based on unjust enrichment is the absence of any juristic reason for the enrichment and corresponding deprivation. I see no legal or equitible reason why a judgment awarded on account of an ostensible obligation to the investors in the ... [second mortgage], should be paid to the general creditors. On the contrary, I find that it would be a travesty of justice if the receiver ... [E. Ltd.] were allowed to recover a substantial award on the ground that . . [E. Ltd.] is obliged to repay the individual investors for this loss of principle, and then, having secured the award, be permitted to say that it was not obliged to pay that amount to the investors. That would mean the receiver, and ultimately the general creditors, would recover for the loss which ... [E. Ltd.] never sustained and never would sustain. That would indeed constitute unjust enrichment.

This "double-barrelled" approach to juristic justification is also used by Chief Justice Dickson in Sorochan v. Sorochan: ${ }^{125}$

The third condition that must be satisfied before a finding of unjust enrichment can be made is also easily met on the facts of this case. There was no juristic reason for the enrichment. Mary Sorochan was under no obligation, contractual or otherwise, to perform the work or services in the home or on the land. In Pettkus the court held that this third requirement would be met in situations where one party prejudices himself or herself with the reasonable expectation of receiving something in return and the other person freely accepts the benefit conferred by the first person in circumstances where he or she knows or ought to have known of that reasonable expectation.

It follows from the preceeding that in both a family and a commercial context it is not essential that a plaintiff establish a reasonable expectation of benefit or some other positive justification for the return of the benefit. Having demonstrated an enrichment, deprivation and a causal connection, the plaintiff should be viewed as having established a prima facie case of unjust enrichment. This may be rebutted by the defendant if a juristic justification can be offered for the retention of the benefit. In the event that such a justification is forthcoming, unjust enrichment is converted into a justifiable enrichment. In truth, therefore, the onus is on the defendant to develop a juristic justification for retention. Obviously the burden is on both the plaintiff and the defendant to lay the evidentiary base upon which a juristic justification for and against restitution can be premised. This suggested approach to onus of proof eliminates the need to fictionalize the intention of the parties.

\section{B. NATURE OF JURISTIC JUSTIFICATION}

Undoubtedly, the most controversial aspect of the law of unjust enrichment continues to be the content of the juristic justification component. The controversy stems from the very concept of juristic justification; that concept can embrace any argument capable of persuad-

124. Supra, n. 35, at 105.

125. Supra, n. 47, R.F.L. at 235. 
ing the judicial mind. ${ }^{126}$ Though in theory there may be a single juristic mind, this is a fiction of the highest order. What is a compelling justification for retention of an asset in the eyes of one judge, may not be for another. However, this is not a legitimate criticism of the law of unjust enrichment. The legal system constantly calls on judges to make decisions in respect of which there may be considerable disagreement; the copious jurisprudence spawned by the Charter provides a contemporary example of this phenomenon. As our experience with the Charter has vividly demonstrated, what is a justifiable incursion of a fundamental right or freedom is very debatable and somewhat subjective. ${ }^{127}$ Undoubtedly, it will be said that it is one thing for judges to be given a constitutional mandate to develop law along "subjective" lines, but quite another for courts to appropriate to themselves this authority. This is a legitimate point, but it has its limits. Even the most uncontroversial common law rule is a product of subjectively based value judgments. For example, the recognition and protection of property by common law and equity is a function of a complicated set of value judgments including the judicial desire to;

(i) efficiently and responsibly exploit resources;

(ii) be fair by rewarding people for the expenditure of their own human capital; and

(iii) create an incentive for productivity.

The appropriate expansion, responsiveness and ultimately the utility of the legal system to the society which it serves requires that judges continue to make "subjective" assessments about the core values of our society. This includes an assessment of what our society believes to be fair. This is not to say that the judiciary should be given a carte blanche to develop law in accordance with its perception of justice. There are limits to the kinds of considerations which the judiciary can legitimately bring to bear in the decision making process. These limits, which should apply when a court is pondering the issue of juristic justification, are an outgrowth of our parliamentary system in which a democratic mandate to govern is conferred. These limits will be discussed below.

Even in the absence of the law of unjust enrichment, the legal system is and has been engaged in making these subjective assessments. When the law did not provide for the recovery of what we would presently call unjust enrichment, it was implicit in cases where there was an enrichment that in the judgment of the legal system the enriched party ought to retain the benefit. The justification for this posture is no less subjective than is the justification for allowing a deprived party to recover. It is merely different. One must acknowledge that absent the law of unjust enrichment there is

126. See Zaidan Group LId. v. Corporation of the City of London (1987) 25 E.T.R. 283 (Ont. S.C.) where Barr J. begins to explore the concept.

127. For illustrative purposes see R. v. Edwards [1986] 2 S.C.R. 713, 35 D.L.R. (4th) 1, where there is division of opinion on the state justification for the Sunday closing laws. See also Collins v. The Queen [1983] 5 W.W.R. 43, 148 B.L.R. (3d) 40, 5 C.C.C. (3d) 141, where the majority and dissenting judges apply the same test to arrive at opposite conclusions. See further the conflicting decisions of the Alberta and Ontario courts of appeal in $R$. v. James Keegstra, unreported, June 6, 1988, Appeal No. 17699 and No. 17701 and $R$. v. Andrews, unreported, [1988] O.J. No. 1222. 
consistency in decision making and predictability in result; but I am not certain whether this is a compliment or a criticism of a legal system that does not subscribe to the law of unjust enrichment. In addition, those concerned with the subjective nature of the law of unjust enrichment should recall that there is historical evidence that through the use of legal fictions the common law system has been unable to resist the temptation to provide relief for unjust enrichment. In Canada the law of quasi-contract and the common intention resulting trust evidences this point. ${ }^{123}$ In England and Australia the doctrine of proprietary estoppel has recently been artificially applied to prevent unjust enrichment. ${ }^{129}$ Resort to such fictions only veils the subjective judgments that are made about the propriety of a defendant's enrichment. Therefore, the argument that the law of unjust enrichment has opened the door to "palm tree justice" is hardly convincing. Judges have (sometimes unwittingly) been involved in the dispensation of subjectively based justice since the earliest days of common law and equity. In Canada, the system has finally matured to the point where it is prepared to admit it. ${ }^{130}$

The challenge for the judiciary is to give shape and content and set limits on the concept of juristic justification. An enriched defendant should only be able to retain a benefit if there are cogent and persuasive reasons for so doing. It is crucial to the development of a consistent and coherent law that the courts state very specifically the justifications for and against the retention of benefits.

\section{CATALOGUE OF JURISTIC JUSTIFICATIONS}

In the process of fleshing out the concept of juristic justification the existing law of restitution should not be forgotten. Goff and Jones summarize and develop the various justifications for the retention of benefits by an enriched defendant recognized by this traditional law. Without exploring fully the content of each of these justifications they are as follows: ${ }^{131}$

(i) the plaintiff conferred the benefit as a valid gift or in pursuance of a valid common law, equitable or statutory obligation which he owed to the defendant;

(ii) the plaintiff submitted to, or compromised, the defendant's honest claim;

(iii) the plaintiff conferred the benefit while performing an obligation which he owed to a third party or otherwise while acting voluntarily in his own self interest;

(iv) the plaintiff acted of ficiously in conferring the benefit;

(v) the defendant cannot be restored to his original position or is a bona fide purchaser;

(vi) public policy precludes restitution.

128. See the text at 411-413.

129. Supra, n. 17.

130. Though rejecting unjust enrichment as a basis of potential liability, the High Court of Australia, in two recent cases, adopted the notion of "unconscionable retention of benefit". See Muchinskiv. Dodds (1986) 60 A.L.J.R. 52 and Bumgartner v. Bumgartner, (Unreported judgments, December 10, 1987). It is suggested that this form of unconscionability is merely a synonym for unjust enrichment. After all, is not the retention of benefit unconscionable because such retention would give rise to unjust enrichment? See Neave, supra, n. 16 at p. 28 where the inter-retlationship between unconscionability and unjust enrichment is explored and where it is suggested that unconscionability may just be another label for unjust enrichment.

131. Supra, n. 7, at 24-42. 
No doubt the Canadian law of unjust enrichment will expand and refine these broad classes of justification. Indeed, as will be noted below, Canadian courts have already embarked on this process. ${ }^{132}$ It is not within the scope of this article to undertake a comprehensive analysis of the concept of justification or to review all of the justifications (both for and against retention of benefit) considered by Canadian courts since the decision in Pettkus v. Becker. Rather, two or three of what are, perhaps, the most controversial areas will be considered.

\section{RECOVERY FOR DOMESTIC OR HOUSEKEEPING SERVICES}

The success which plaintiffs have enjoyed in obtaining restitution for contributions of domestic services to cohabitation relationships suggests that Canadian courts may not be strictly wedded to the notion put forth by Goff and Jones, that if a plaintiff has conferred a benefit on a defendant while acting voluntarily in his or her own self interest, restitution will be denied. Goff and Jones support their assertion (though they acknowledge contrary authority) by citing the English case Ruabon Steamship Company v. The London Assurance, ${ }^{133}$ and the American case of Ulmer v. Farnsworth. ${ }^{134}$ In the former case a vessel covered by a policy of marine insurance was damaged by a hazard for which it was insured. Consequently, the vessel put into dock so that necessary repairs could be made. While docked the owners surveyed the ship for the purpose of having its classification renewed by the insurer, even though such a survey and classification did not have to be done for a period of nine months. The insurers sought a court order to compel the owners of the vessel to contribute to the expenses of docking on the theory that the vessel owners had acquired a benefit at the insurer's expense. That is, the owners had been spared the expense associated with docking the ship for the survey that was necessary for the next classification. Lord Halsbury considered this tack unacceptable, commenting that he could not "understand how it can be asserted that it is part of the common law that where one person gets some advantage from the act of another a right of contribution towards the expense from that arises ... ${ }^{135}$ To emphasize this point he stated that the logical conclusion of the plaintiff's theory was "... that if a man were to cut down a wood which obscured his neighbour's prospect and gave him a better view, he ought upon this principle to be compelled to contribute to cutting down the wood"..$^{136}$ In the Ulmer case a quarry owner was denied the restitution he sought of the benefit acquired by his neighbour when the quarry owner pumped his own quarry dry and thereby eliminated water from his neighbour's quarry. After reviewing these cases, Goff and Jones

132. In the International Corona case, supra, n. 74 at 70 the Ontario Court of Appeal commenting on the Goff and Jones analysis of the "change of position" defense state that the circumstances of the case "justify going further" than Goff and Jones "propose".

133. [1900] A.C. 6 (H.L.).

134. 15 A. 65 (Maine S.C. 1988).

135. Supra, n. 133, at 10.

136. Id. at 12. 
[VOL. XXVI, NO. 3

outline what they perceive to be the "sound reasons" 137 for denying recovery in such cases. They state: ${ }^{138}$

\begin{abstract}
The defendant may not have received an incontrovertible benefit, in the sense that he had been saved an expense which he would inevitably have incured. But, more fundamentally, to grant restitution in every case where a plaintiff had acted in his own self-interest would be to open a Pandora's box of claims, in circumstances where self-interest should be its own incentive and reward.
\end{abstract}

There are several reasons why plaintiffs in quasi-matrimonial cases should not be precluded from succeeding on the basis of the self-interest action principle. First, in some of the cases the plaintiff will have conferred an incontrovertible benefit on the defendant. For example, if the defendant has young children who would need the care actually provided to them by the plaintiff, this may well be an incontrovertible benefit. Secondly, the case for applying the principle of self-interested action may be stronger when the plaintiff and the defendant are strangers or are in a business relationship, especially where the outlay is one for business purposes. Thirdly, in the cohabitation cases the plaintiff's actions may not be exclusively motivated by self-interest. Where this is the case Goff and Jones acknowledge that the plaintiff may succeed in a restitutionary action. ${ }^{139}$ In principle, therefore, it is open for a plaintiff to succeed in an unjust enrichment action even though his or her contributions may have been motivated, at least partially, by self-interest.

But is there anything unique about the nature of the contribution of domestic services which should preclude the contributor from succeeding in an action for unjust enrichment? Professor McLeod has answered this question in the affirmative, citing as justification, community expectations and the expectations of the persons involved. ${ }^{160} \mathrm{He}$ notes that when the law is "totally out of line with community expectations, it is doomed to failure in the long run". ${ }^{141}$ Professor McLeod does not tell us how he was able to assess community expectations. It is my perception that Professor McLeod may be reflecting moral precepts of a previous generation and that the community at large may be receptive to the notion that contribution of domestic services to a relationship is as valid as any other form of contribution that may give rise to an enrichment. In this regard I would note, what may be viewed by some as the surprising results of a Gallup poll, in which the public demonstrated its support for the philosophy that assets accummulated during marriage should upon dissolution be equally divided..$^{142}$ While I appreciate that the poll measures opinions about a significantly different issue, this may be a signal that the Canadian public

137. Supra, n. 7, at 34.

138. Id.

139. Id.

140. See, Annotation to Herman v. Smith, supra, n. 89, at 156.

141. Id.

142. This Gallup poll is referred to in a Toronto Daily Star article cited in Ziff's Cases and Materials on Family Law and Policy (1987) at p. 3. (undated). The headline reads "75\% believe assets of marriage should be split equally, poll says." The poll was conducted April, 1986 and the results released May 22, 1986. See also the Alberta Institute of Law Research and Reform Report No. 18 on Matrimonial Property (August, 1975) where similar and more emphatic survey results are discussed. 
has rather liberal attitudes about the division of wealth generated during a cohabitation relationship.

In terms of Professor McLeod's assertion that compensation for domestic services should not override the intentions of the parties concerned, no doubt if there is an agreement or, perhaps, even tacit understanding to this effect, Professor McLeod is on solid ground. However, if the parties merely expect that domestic services will go unrewarded, as opposed to agreeing to or approving of the morality of this arrangement, I would suggest that the parties expectations should not have an impact upon the issue. Similarily, if a potential plaintiff is merely resigned to the notion that there will not be recovery for contribution of domestic services, this should not bar the possibility of restitution. Pessimism about the law should never itself be a self-fulfilling prophecy.

A variation of Professor McLeod's point focuses on the intention of the contributing party. Professor Haydon has suggested that the provision of domestic services should ordinarily be regarded as a gift. ${ }^{143}$ In particular he has stated:14
Many women therefore risk co-habiting with a man in the hope that marriage will follow, while many men take advantage of this by deferring marrige for as long as they can. The majority of such women surely make a gift of their housewifely services or are happy to perform them in return for board and lodging, holidays and a good time.

Haydon's point is reminiscent of the trial decision in the case of Pettkus v. Becker where the trial Judge found that the plaintiff's contribution to household expenses was intended to be a gift "in the nature of risk capital invested in the hope of seducing a younger Defendant into marriage". ${ }^{45}$ Ritchie J. was able to side-step this finding of fact, which he described as "gratuitously insulting", 146 by a particularly fictional invocation of the common intention resulting trust. ${ }^{147}$

Though logically sound, Haydon's approach is undermined by probative problems. His approach assumes that a gift of services is intended to be unconditional in the sense of surviving any potential termination of the relationship. It is suggested that it is much more reasonable, and in accord with the undercurrents of contemporary Canadian law, to assume that the donor is contributing services on the condition that the relationship last. The assumption of self-interested action lies at the very heart of the recent repudiation of the presumption of gift in favour of the presumption of resulting trust. ${ }^{148}$ Only if the defendant can establish an actual and specific intention to make a gift of domestic services irrespective of the continuity of the relationship should the defense of gift be countenanced. In practice

143. Supra, n. 6, at 3 .

144. Id. at 3-4.

145. See Ritchie J's judgment at the Supreme Court of Canada where he quotes the trial Judge and reviews the evidence in question. Supra, n. 1 at 862.

146. Id.

147. Such a finding implies that the intended donee of the contribution, Mr. Pettkus, did not accept the intended gift but preferred to hold the contribution on trust for the plaintiff, Ms. Becker. Obviously this is fictional to an extreme.

148. See Rathwell v. Rathwell, supra, n. 2, D.L.R. at 304 and Wilson v. Monroe, supra, n. 51, at 179-181 and cases cited therein. 
whether an alleged unconditional gift is motivated by a desire to entice a donee to marry the donor, or the anticipation that the donor will be supported during marriage, defendants will rarely be able to discharge the onus of proving such a specific intention. Moreover, it would be wrong for the courts to make inferences favourable to the defendant in respect to an allegation of gift. ${ }^{149}$

On the other hand, the benefits received by a party who has contributed housekeeping services to another, such as board and lodging, should impact on the unjust enrichment equation and, in most cases, it is suggested, should negative restitution for such services. The different contributions of the parties to each other must surely give rise to a set off. However, it would be wrong in principle to bring accounting like precision to the set off. Support and household contributions are part of the "give and take" of a relationship and only when one of the parties' contributions is substantially out of proportion to that of the other should the law intervene. ${ }^{19 \mathrm{~A}}$ Any other conclusion would introduce a "balance sheet mentality" into relationships and would impose on the legal system the intolerable burden of inquiring into every detail of a cohabitation relationship and evaluating every contribution. The wisdom of contract law in not inquiring into the adequacy of consideration would be well adopted by the law of unjust enrichment. An incidental benefit of this set off approach is that it avoids the speculative and/or revisionist exercise of "assessing" the attitudes of the community at large, and the parties toward the issue of accounting for contribution of domestic services.

The suggested balancing approach is conspicuous by its absence in the Supreme Court of Canada's decision in the case of Sorochan v. Sorochan. ${ }^{150}$ No doubt Mary Sorochan contributed enormously to Alex Sorochan, but the final remedy in that case can only be fully supported on orthodox unjust enrichment principles if Alex Sorochan contributed nothing to Mary's maintenance. The propriety of looking at benefits conferred by a defendant on a plaintiff had been established prior to Sorochan in several lower court cases. ${ }^{151}$ Nevertheless, Dickson C.J. in Sorochan made no reference to Alex's contributions. The reason for this, in my view, is that at least in part, Sorochan is not truly an unjust

149. See Neave, supra, n. 16 at 7.

149A. See also Stefaniuk v. Stefaniuk (1987) 48 Man. R. 111 (Man. Q.B.) at 117 where Mullaly J., in dismissing a claim notes, inter alia, that the claimant who was seeking restitutionary compensation for improvements made by him "did little more than what any husband or father could be expected to do for his wife and children. ..." Refusing restitution on the ground that the plaintiff's contributions were founded upon his or her duty has some merit, though it is doubtful that the plaintiff was legally obliged to make the improvements. Mullaly J.s point does not really focus on duty. Rather it stresses that usual and expected contributions to a relationship should not found a restitutionary action. This is correct, I would suggest, because these contributions form part of the give and take of cohabitation relationships.

150. Supra, n. 47.

151. See, for example, Yonke v. Thompson Estate (1981) 14 Sask. R. 129 (Q.B.), Folley v. Thauberger (1980), 29 R.F.L. (2d) 329 (B.C.C.A.), Coffin v. Ellis (1982) 36 B.C.L.R. 258 (S.C.), Chisson v. Duguay (1983), 52 N.B.R. (2d) 212, 137 A.P.R. 212 (Q.B.) and Tocher v. Lind (1984) 41 R.F.L. (2d) 103 (B.C.S.C.). 
enrichment case. Rather, it is a case in which the Supreme Court of Canada expressed its view that some relationships should be treated as spousal in nature and upon dissolution give rise to a matrimonial property like division of wealth acquired or maintained during the relationship. What qualifies as a relationship for this sort of treatment is unclear, although it may be that the primary factor is the longevity of the relationship. In Sorochan the parties lived together as husband and wife for 42 years. ${ }^{152}$

If Mrs. Sorochan's success cannot be fully rationalized on unjust enrichment principles, how can her success be explained? The answer may well be the "good conscience" constructive trust. The Supreme Court may be indicating that in the dissolution of relationships which are truly tantamount to spousal, assets acquired or retained during the relationship should be divided not only to reflect actual contribution by the parties but also the philosophy of economic union which pervades the various matrimonial property regimes. In other words, in the Court's view it is unconscionable for one party to retain all the assets of a relationship and the other, who has contributed significantly to the acquisition or retention of the assets, to fend for him or herself at an "advanced" age, without any material proprietary support. I am not suggesting that this is an appropriate use of such a trust, but rather merely that it may explain the result in Sorochan. Of course, some may regard such an approach as a serious and unmandated intrusion by the judiciary into the area of public policy. However, to the extent that Sorochan cannot be explained by unjust enrichment principles, it may simply be a very hard case that has made bad law.

The decision in Davidson v. Worthing, illustrates the danger inherent in the Sorochan case. In that case McEachern C.J., in dicta, rejected "the suggestion that Miss Davidson should fail [in her action for unjust enrichment] just because she possibly received as much by way of 8 years' maintenance for herself and her children as she gave". ${ }^{153}$ From the point of view of the law of unjust enrichment, this is a highly dubious proposition. If Miss Davidson's action should not fail because Mr. Worthing provided her with as much as she provided him, then it follows that a counter-suit brought by Mr. Worthing should not fail merely because Miss Davidson contributed as much to him as he did to her. While Sorochan is to be applauded for reminding us of the appropriate breadth of the concept of enrichment, it does cloud the issue of when domestic services should be viewed as a contribution. On this point the decision should be understood as a special case, decided in rather unique circumstances and, therefore, not of general precedential value. As noted above, only when the

152. In Sorochan, Dickson C.J. commented that longevity of cohabitation is a consideration which impacts on whether relief is proprietary or personal and that the length of the claimant's relationship with the defendant constituted "a compelling factor in favour of granting proprietary relief". Supra, n. 47, R.F.L. at 241 . It is unclear why length of relationship has any bearing on the question of whether relief should be proprietary. Indeed, longevity per se should have no bearing on the substantive question of whether unjust enrichment exists.

153. Supra, n. 59 at 66. 
contribution of domestic services is substantially out of proportion to the benefits acquired from the other party, should there be restitution for such services.

\section{E. JURISTIC JUSTIFICATION AND STATUTORY POLICY}

If the recognition of an unjust enrichment claim would have the effect of frustrating the underlying policy, purpose or operation of a statute, then a juristic reason exists for not recognizing the claim. Obviously, legislative policy, whatever its content, must be considered to be paramount over the concern of preventing unjust enrichment. This paramountcy stems from the fundamental notion of legislative supremacy. Of course, whether, in any given case, the application of the doctrine of unjust enrichment would in fact conflict with a statutory regime requires a very close examination of the statute at issue. In the construction of statutes there exists a presumption that they are to be interpreted so as not to abrogate the common law ${ }^{154}$ and it follows, therefore, that presumptively the law of unjust enrichment will survive a statutory enactment. In other words, it is a rule of construction of statutes that they be read so as not to authorize or mandate, or preclude the remediation of, unjust enrichment. ${ }^{14 A}$

\section{Unjust Enrichment and Matrimonial Property Statutes}

The question of whether the doctrine of unjust enrichment is compatible with a particular statutory regime has arisen in Canada primarily, but not exclusively, in respect to matrimonial property statutes. Generally, such statutes create a deferred sharing of property system in which certain property is subjected to a presumption of equal sharing and other property is not. Some statutes apply this presumption to property accumulated during the marriage ${ }^{155}$ and others to assets used for family purposes. ${ }^{136}$ Combination systems also exist. ${ }^{157}$ Under all regimes certain designated property is exempted from the operation of the presumption of equal sharing. To this point several cases have considered whether the law of unjust enrichment is compatible with particular matrimonial property statutes. Though the majority of these cases consider the issue in the context of the Ontario Family Law Act, it is suggested that the predominant view expressed in these cases, that the remedial contrustive trust does,

154. See National Assistance Board v. Wilkonson [1952] 2 Q.B. 648 at 661, [1952] 2 All E.R. 255 (Q.B.) per Lord Devlin and Doncaster Amalgamated Collieries [1940] A.C. 1014 at 1031 (H.L.) per Lord Atkin.

154A. It is suggested that a parallel rule of construction exists in respect to contracts. Unless a contract explicitly or by necessary implication provides for what would otherwise be unjust enrichment, it should be construed so as not to give rise to it. Ambiguous clauses should be construed so as to prevent rather than create unjust enrichment.

155. See, for example, the Alberta Matrimonial Property Act, R.S.A. 1980, c. m-9, the Ontario Family Law Act, 1986, c. 4 and the Saskatchewan Matrimonial Property Act, S.S. 1979, M6-1.

156. See, for example, the Prince Edward Island Family law Reform Act, S.P.E.I. 1978, c. 8 and British Columbia Family Relations Act, R.S.B.C. 1979, c. 121.

157. Manitoba Marital Property Act, 1978 (Man.), c. 24 (also C.C.S.M., c. M45) and Nova Scotia Matrimonial Property Act, S.N.S. 1980, c. 9. 
notwithstanding the statute, have some scope for operation, is applicable across jurisdictional lines. In the recent Ontario Court of Appeal decision in Rawluk v. Rawluk ${ }^{158}$ the Court explicitly disapproved of the contrary view expressed in the two lower court decisions of Benke v. Benke ${ }^{159}$ and Leonard v. Leonard ${ }^{160}$. In Rawluk, the Court reasoned that the constructive trust remedy: ${ }^{161}$

... gives the claimant an interest in property because justice requires it. We do not think that the remedy of the equalization payment under the Act substantially or necessarily accomplishes the same purpose as that of the constructive trust, or that giving effect to a valid constructive trust claim interferes with the scheme of the Act and, accordingly, that the statutory remedy has by necessary implication repealed the equitable remedy.

Both the Rawluk ${ }^{162}$ and Leslie ${ }^{163}$ cases recognize that a preliminary step to an equalization payment under the Ontario statute may be the determination of ownership of property that must be evaluated in order to calculate the equalization payment. Certainly, no policy objective or statutory mechanism would be advanced by excluding the law of unjust enrichment from impacting on this threshold question. Indeed, it would make as much sense to exclude the law of unjust enrichment from this initial process as it would to exclude property law generally. However, in respect to many if not most applications under the various statutes there will be no practical reason to delve into subtle questions of equitable ownership of non-exempt assets. Often equalization payments can be made without inquiring into ownership beyond the question of title. For example, if one spouse has title to all assets, an equalization payment for half the value of the assets can be ordered. No purpose would be served in going beyond the question of legal ownership. Where non-exempt property to which no formal legal title exists, a court can order, without inquiring into the question of equitable ownership, that all assets vest in one spouse and impose upon that spouse the obligation to make an equalization payment. Alternatively, in this situation the court may order a division of assets and set off the value of the assets vested in each spouse in order to quantify the equalization payment. Again, in this situation it will be unnecessary to determine equitable ownership. Similarly, where both spouses are titled, it may be most convenient and effective to divide the assets along the lines of actual title and subsequently valuate the assets in order to allow for the necessary set off. Again, no inquiry into equitable ownership is necessary. In principle, the need to inquire into equitable ownership should be no greater in cases where a court is prepared to exercise its discretion to depart from the presumption of equal ownership. On the other hand, a court's discretion in allocating particular assets to each spouse, whether the marital estate is distributed equally or unequally,

158. Rawluk v. Rawluk (1986) 55 O.R. (2d) 704, 3 R.F.L. (3d) 113, 23 E.T.R. 199, 29 D.L.R. (4th) 754 (H.C.); affd (1987) 10 R.F.L. (3d) 113 (Ont. C.A.); leave to appeal to S.C.C. granted.

159. Benke v. Benke (1986) 4 R.F.L. (3d) 58 (Ont. D.C.).

160. Leonard v. Leonard, unreported, [1987] W.D.F.L. 1099 (Ont. Dist. C.).

161. Supra, n. 158, 10 R.F.L. at 115.

162. Both the trial Judge and the Court of Appeal make this point. Supra, n. 158, 3 R.F.L. 120-121 and 10 R.F.L. 115 and 116 respectively.

163. Leslie v. Leslie (1987) 9 R.F.L. 82 at 92 (Ont. S.C.). 
might be affected by the state of beneficial title arising from a restitutionary constructive trust. In summary, though in theory it is permissible to invoke the law of unjust enrichment to determine the pre-equalization state of ownership of non-exempt assets, only occasionally will it be necessary to do so. As an ancillary matter, though in any given case the state of equitable title may not be explored prior to a court making an order under a matrimonial property statute, it would be implicit that such title is "washed away" by such an order.

While it is permissible to apply the law of unjust enrichment to determine in a preliminary way, the state of equitable title to marital assets, there is little doubt that if this law was the final arbiter of the division of non-exempt property, unjust enrichment would undermine the presumption of equal sharing that is so central to the array of matrimonial property statutes. Certainly, the law of constructive trust should not be utilized to outflank the central objective of these statutes. This point seems to have escaped the Ontario Supreme Court in the recent controversial case of Caratun v. Caratun. ${ }^{164}$ The Ontario Family Law Act firmly entrenches the presumption of equal sharing by making it clear than an unequal division of value of non-exempt property is only justified where equal division would be "unconscionable". ${ }^{165}$ Departure from the equal division principle cannot, as Madam Justice Van Camp recognized in Caratun, be justified on the ground that equal division would be merely "inequitable". ${ }^{166}$ The reasoning in Caratun undermines this firm policy and does so through the mechanism of the unjust enrichment constructive trust.

In a judgment that bristles with difficulties, Van Camp J. concluded that $\mathrm{Mr}$. Caratun was a constructive trustee of his dental license to the extent of $\$ 30,000.00$ of its capital value of approximately $\$ 379,000.00$. This conclusion was preceded in the judgment by the opinion that a dental license was property for both the purposes of the Family Law Act and the proprietary aspect of the law of unjust enrichment. ${ }^{167}$ After noting that there were alternative methods for compensating spouses for their contributions to the acquisition by their married partners of a professional degree or

164. Caratun v. Caratun (1986) 9 R.F.L. (3d) 337 (Ont. S.C.).

165. Ontario Family Law Act, supra, n. 155, s. 5(6).

166. Supra, n. 164, at 352.

167. Id. at 351 and 355 . This conclusion was rejected in Linton v. Linton (1988) 11 R.F.L. (3d) 444 at 457-458. It is beyond the scope of this article to analyze the difficult policy issue of whether a degree or licence may be the subject matter of property rights. However, it should be noted that a negative answer to this question does not displace the potential impact of the law of unjust enrichment in cases where a claimant is demanding compensation for contributions made towards the acquisition by a defendant of a qualification in the nature of a degree or licence. If all of the elements of unjust enrichment are present, a restitutionary claim may be pressed on the theory that the claimant's efforts contributed to the acquisition of a valuable non-proprietary asset. If degrees or licences are not property this would preclude proprietary remedies from attaching to them. However, the personal remedy of damages would still be available to rectify the unjust enrichment. Whether courts in their equitable jurisdiction would be sufficiently inventive so as to award reviewable periodic payments, remains to be seen. Having regard to the vagaries of realizing on the value of qualifications such as degrees and licences the courts should adopt such an approach. 
license, including alternatives under the Family Law Act, Van Camp J. stated: 168

In my opinion, the constructive trust is the first method to consider for compensating a spouse for his or her contribution to the other's professional licence or degree, since it provides a proprietary interest to the contributing spouse, of fers sufficient flexibility to deal equitably with both spouses, and is in keeping with the preamble of the F.L.A.

She also added that in her opinion "any of [these] ... methods are open to the court under the Act and the method used will be that which is most fitting to the facts". ${ }^{169}$ It should be apparent that this form of analysis adopts the remedial constructive trust as the final arbiter of the division of non-exempt assets which the Ontario Legislature has indicated should be divided on the basis of the firm presumption of equal sharing. The constructive trust solution may well be more equitable than the statutory treatment of the division of "property" in the nature of a license or degree, but it is not the solution of the Ontario Legislature. Ultimately, Madam Justice Van Camp in Caratun is expressing her preference for a more flexible statutory regime for the division of marital property or, at least, "property" in the nature of a professional accreditation, than that found in the Ontario statute. Even accepting the weaknesses of the Ontario Act, I would suggest, she has gone too far. As Van Camp J. realized, she might have been able to arrive at the same final result, namely, an unequal division of the value of the license, under the theory that "equalizing the value of licences and degrees", "because of their unique nature and because of the need for a continuing effort by the holder in order to realize their full value", "will always be unconscionable". ${ }^{170}$ Van Camp J's theory, that property subject to the presumption of equal sharing can be taken outside of the Act and divided on the basis of non-statutory principles, has recently and forcefully been repudiated by Kileen L.J. in the case of Linton v. Linton. ${ }^{17}$

Where property is exempt from the presumption of equal sharing, and also beyond any other distributive discretion created by a particular matrimonial property statute, different considerations apply. There is no reason in principle why the law of unjust enrichment and its proprietary remedy of constructive trust (or for that matter any other property doctrine) should not be the final arbiter of the ownership of this kind of property. In Alberta, such exempt property includes property acquired by a spouse through inheritance..$^{12} \mathrm{~A}$ court cannot order an equalization payment in respect to the capital value of such an asset as of the date of inheritance or marriage, whichever is later, and cannot (properly) take into account that exempted value in exercising its discretion to depart from the presumption of equal sharing in respect to non-exempt assets. What is the position if the value of the inherited property has been maintained through

168. Supra, n. 164, at 356 .

169. Id.

170. Id. at 352 .

171. Supra, n. 167 , at 457 . See also James G. McLeod's annotation to the Litton case in 1988,11 R.F.L. (3d) 444 at 445.

172. Alberta Matrimonial Property Act, supra, n. 155, s. 7(2)(b). 
the efforts of the non-titled spouse? Because the statute is silent on this point three possible conclusions can be drawn. It is possible to conclude that the legislature intended to preclude the non-titled spouse from obtaining restitution, or that the legislature either did not advert to this point, or intended to allow recovery. The last two possibilities are consistent with restitution because recovery would not conflict with legislative intent. It is suggested that it would be incorrect in principle to impute to the legislature the dishonourable intention of denying restitution of property to a party unjustly impoverished. Therefore, where a statute does not purport to regulate property in any way, where it has taken pains to expressly exclude property from its umbrella, the statute should not be interpreted as precluding the application of standard proprietary principles, including the law of unjust enrichment, to determine entitlements. Any other view would give the statute an over-inclusive impact.

In many matrimonial property statutes, property which is exempt from the presumption of equal sharing is subjected to a general distributive discretion. For example, section 23(4) of the Saskatchewan Matrimonial Property Act provides as follows: ${ }^{173}$

Where the court is satisfied that it would be unfair and inequitable to exempt property from distribution, the court may make any order that it considers fair and equitable with respect to the [exempt] matrimonial property mentioned in this section.

Applying the remedial constructive trust as the final arbiter of ownership of s. 23 exempt property would undermine the specific intent of the Saskatchewan legislature to subject even exempt property to a judicial distributive discretion. However, as is the case with non-exempt property, there can be no objection to applying the law of unjust enrichment to determine, in a preliminary way, the ownership of the affected property. Undoubtedly, the imposition of a constructive trust on exempt property which is subjected to a distributive discretion will have a much greater impact on the final question of ownership, than the imposition of a constructive trust on non-exempt property. The reason for this, of course, is that the value of non-exempt property is presumptively, and in terms of incidence, almost always, redistributed on an equal sharing basis. Exempt property which is subject to a distribution discretion is not subject to a presumptive redistribution of any sort and, therefore, will be redistributed under the court's discretion less often than non-exempt property.

In conclusion, whether property is regulated by a presumption of equal sharing or is subject to a general discretion as to its division, courts may resort to the constructive trust to determine the state of ownership of assets prior to the operation of a matrimonial property statute. In the case of non-exempt property, it will often be unnecessary to consider whether a particular asset is subject to a constructive trust. With respect to exempt property that is subject to a distributive discretion, the imposition of a constructive trust will be more meaningful as it will often be determinative of ownership. With respect to exempt property that is not subject to a distributive discretion, the imposition of a restitutionary constructive trust will and should be the final arbiter of the state of beneficial title.

173. Supra, n. 155. 


\section{Unjust Enrichment and Other Statutes}

In the non-matrimonial property context, the Ontario Supreme Court has also indicated that unless a statute clearly or by necessary implication is incompatible with the doctrine of unjust enrichment, the doctrine will have continued application. In Zaidan Group Ltd. v. Corporation of the City of London, ${ }^{174}$ Barr J. considered the issue of whether the plaintiff was entitled to interest on an overpayment of property tax. The plaintiff had appealed its property tax assessments for the years 1981 to 1984 , but was compelled to pay in full pending the final resolution of its appeal. When the plaintiff succeeded in its appeal, the City of London rebated the overpayment but refused to pay interest thereon. The evidence indicated that the plaintiff's overpayment was not kept in a separate account and that any tax funds in excess of the City's immediate requirements were invested during the period in question, at a rate of $103 / 4 \%$. Two statutes were referred to by Barr J., the first being the Ontario Assessment Act, which provided in s. 36(6) that any overpayment of tax ". . . shall be refunded by the municipality". ${ }^{175}$ The second statute, the Ontario Municipal Interest and Discount Rates Act, 1982, authorized a local municipality to pass by-laws for the payment of interest on overpayments refunded under the Assessment Act ". . . at such a rate as the council may determine ...". ${ }^{176}$ On these facts, Barr J. held that the doctrine of unjust enrichment warranted the finding that the City was constructive trustee of the overpayment and the interest on the overpayment calculated at a rate of $103 / 4 \%$ per annum. In respect to the interest, he rejected the argument that the Municipal Interest and Discount Rates Act was a juristic justification for refusing to apply the law of unjust enrichment. He reasoned as follows: ${ }^{17}$

The section neither expropriates the interest for the municipality nor gives a municipality a right to do so. Counsel for the City submits that by implication the section gives the council sole right to determine whether persons will receive interest on the overpayments. It is entirely possible that the Legislature did intend that no interest would be paid on the overpayment unless the municipality passed such a by-law. But s. 6 certainly does not say this. Of course, in a case where the municipality had not received income from the overpayment, the section would authorize the municipality to pay interest if it chose to do so.

After referring to the presumption that statutes should not be construed to alter the common law, Barr $\mathrm{J}$. further concluded that authorizing a trustee to keep income generated by a trust fund would be a "substantial alteration" of the law. ${ }^{188}$ In my view, Barr J. is plainly correct. Applying unjust enrichment law to the interest on the overpayment does not undermine a probable legislative policy manifested by the Municipal Interest and Discount Rates Act. It is hardly likely that the Ontario legislature intended to authorize a municipality to expropriate monies in the form of interest on funds owned by one of its taxpayers. More likely,

174. Supra, n. 126.

175. R.S.O. 1980, c. 31.

176. S.O. 1982, c. 44, s. 6(1).

177. Supra, n. 126, at 292.

178. Id. at 293. 
the Legislature operated under the supposition that there was no basis in law for the taxpayer to insist on the interest of an overpayment, and, therefore, its intention vis a vis the taxpayer was benevolent rather than malevolent. It is also possible that the Legislature authorized the creation of a mechanism for the payment of interest for accounting purposes. A municipality making a payment of interest could point to a by-law passed pursuant to the Municipal Interest and Discount Rates Act as authority for providing a taxpayer with interest. Absent this authority there might be some question as to the propriety of the payment of such interest.

The law relating to the inter-relationship between juristic justification and statutory policy was also triggered but not considered in the International Corona ${ }^{179}$ case. It will be recalled that Lac acquired a gold field in breach of its fiduciary duty and duty of confidence. After being notified of Corona's claim to the land and, indeed, after registration by Corona of a lis pendens, Lac constructed a mine and mill. At trial Holland J. ordered Lac to transfer the field to Corona but required that Corona pay Lac \$154 million, the value of the improvements. The basis of the latter order was s. 37(1) of the Conveyancing and Law of Property Act. ${ }^{180}$ In essence, this section provides that when a person improves another's land in the belief that the land belongs to him or her a lien may arise in favour of the improver to secure the value of the improvements. The Ontario Court of Appeal rejected Holland J's conclusion that Lac was entitled to the benefit of the statute. It held that Lac's knowledge of Corona's claim of ownership took Lac outside of the protection of the statute. Lac was aware of the weakness of its title, and, therefore, could not be said to possess the honest belief that it was improving its land. ${ }^{181}$ Nevertheless the trial Judge's order that Lac was entitled to $\$ 154$ million and a lien to secure that amount was affirmed. The affirmation was founded on the view that to deny Lac restitution for its expenditure would in itself give rise to unjust enrichment. This point was made emphatically as follows: ${ }^{182}$

The sheer magnitude of the enrichment of, or benefit confered on, Corona if LAC were
denied a lien cannot be ignored, particularly in light of the reality that the expenditures
made by LAC to make the property productive inevitably would have been required on
the part of Corona had there been no breach of the constructive trust. The principles of
equity, in our view, need not be employed in a manner that itself creates an unjust
enrichment or disturbs the conscience of the court.

But can it not be said that the "good faith" requirement found in $\mathrm{s.} 37$ is a juristic reason for refusing to remedy what would otherwise be a case of unjust enrichment? That is, can it be argued that the enactment allows recovery for the value of improvements only in cases where improvers believe that they are building on their own land? This point may not have been argued and certainly was not adverted to in the reasons for judgment of either the trial or appeal courts. It is suggested that treating the statute as a juristic justification for denying restitution would subert and not

179. Supra, n. 74.

180. R.S.O. 1980 , c. 90.

181. Supra, n. 74, O.R. at 68-69.

182. Id. at 70. 
advance the underlying goal of the enactment which undoubtedly is to prevent unjust enrichment. This legislative goal and the particular doctrinal basis for effectuating it found in the section was developed well before the maturation of the law of unjust enrichment. ${ }^{183}$ The interface between the law of unjust enrichment and the statute has to be assessed with this in mind. Surely the enactment was merely a response to a very common but, nevertheless, very specific factual pattern in which other elements which would today inform the law of unjust enrichment were absent. To suggest that the section amounts to a complete code which has the effect of limiting the law of unjust enrichment to the single consideration of good faith, is to attribute to the legislature an intention to discount obviously relevent factors such as incontrovertible benefit, change of position, etc. Even if such a narrow legislative intent is plausible, in the absence of a clear indication to the contrary, the legislation ought to be interpreted so as to maximize the underlying policy objective of avoiding unjust enrichment. Displacing the law of unjust enrichment, even in part, does and should require a clearer legislative signal than that provided in s. 37.

Having regard to the foregoing, it should be apparent that the mere fact that a statute purports to regulate property that may be the subject matter of a remedial constructive trust does not, in itself, preclude the imposition of such a trust on the regulated property. A close analysis of the terms and underlying purpose of a statute is required in order to determine whether a policy, purpose or mechanism of a statute would be frustrated by the recognition of the trust.

\section{F. JURISTIC JUSTIFICATION AND THE INTENTION OF THE PARTIES}

There appears to be some confusion over the interrelationship between the remedial constructive trust and the intention of the potential constructive trustee and beneficiary. It would seem obvious that if parties to a particular transaction contract for a particular result, in the absence of compelling circumstances, that result ought to obtain. If it were otherwise the courts would be deluged with unjust enrichment claims and reasonable expectations of parties would be undermined. It is not at all unusual for one party to a contract to get more out of the contract than the other. Indeed, very frequently that is the very object of the contracting process. Therefore, the mere fact that one of the parties has struck a good bargain is no justification for judicial alteration of the bargain. That the courts should not lightly interfere with the intentions of contracting parties may seem a rather trite point, especially when the cases recognize that a contract or other form of obligation may be a juristic justification for refusing to correct an enrichment. ${ }^{184}$ Unfortunately, this trite point has not had universal judicial acceptance. It would seem that some of the courts which

183. This type of legislation can be traced back in Canada to at least March 29,1873 when the Ontario legislature enacted An Act for the Protection of Persons Improving Land Under a Mistake of Title, S.O. 1873 c. XXII.

184. See Rathwell v. Rathwell, supra, n. 2, W.W.R. at 114. 
have resisted the principle of non-interference have been led astray because they have been too literal in their interpretation of general statements about the character of constructive trusts.

Standard texts commonly refer to constructive trusts as being imposed regardless of intention. ${ }^{185}$ Generations of law students have been told that constructive trusts are imposed by operation of law and their existence is not dependant upon, as is the case with express trusts, the intentions of settlors. As Dickson J. (as he then was) observed in Rathwell v. Rathwell, the constructive trust is "imposed irrespective of intention; indeed, it is imposed against the wishes of the constructive trustee". ${ }^{186}$ However, it does not follow, as MacKenzie J. asserted in the recent case of Duncan v. Duncan, that "[i]n the case of a constructive trust the question of intent is not relevant." 187 It is one thing to say that a constructive trust does not arise from the intention of the parties, but it is a non sequitor to then conclude that the parties' intentions are irrelevant to the question of whether the trust has arisen. Unfortunately, this latter proposition was put forth in the Saskatchewan case of Waselenko v. Touche Ross Ltd. ${ }^{188}$ In that case, a construction company had agreed to build at its plant a pre-fabricated house for the plaintiffs and to receive payments in stages. After approximately one-half of the payments were made and the house was partially completed, the company went into receivership. The receiver refused to complete the house because the estimated cost of completion was greater than the amount owing. The plaintiffs brought an application seeking an order that the house was held on trust for them and that it did not form part of the insolvent estate of the company. The trial Court upheld their claim despite a clause in the contract saying that the property in the house remained in the company until delivery. Geatros J. stated that the agreement between the plaintiffs and the company was not "conclusive of the matter". ${ }^{189} \mathrm{He}$ reasoned: "[ $\mathrm{t}$ ] hat is so because the remedial constructive trust arises by operation of law. So it does not allude to intention."190 Taken to its extreme, this reasoning suggests that pre-cohabitation contracts dealing with property ownership will be disregarded in cases where remedial constructive trust analysis is applicable. This is patently incorrect and such a view relegates the constructive trust to the mischevious role of undermining the fully informed and formalized intentions of parties. ${ }^{191}$

The case of Berrett v. Henberry ${ }^{192}$ demonstrates that the intention of parties may preclude the imposition of a remedial constructive trust. The

185. See Waters, Law of Trust in Canada, supra, n. 5, 377.

186. Supra, n. 2, D.L.R. at 305.

187. Supra, n. 121, at 172.

188. (1983) 14 E.T.R. 125; affd [1985] 3 W.W.R. 38 (Sask. C.A.).

189. Id. at E.T.R. 130.

190. Id.

191. It should be added that Waselenko was ultimately correctly decided because the contractual clause dealing with the retention of property rights until delivery of the pre-fabricated home was intended to provide security for the construction company's right to the purchase monies. It was not intended to determine the beneficial ownership of the pre-fabricated home at any stage in the construction process.

192. (1984) 61 N.S.R. 428 (S.C.A.D.). 
appellant and respondent had pooled their savings and purchased property as joint tenants. The appellant, who had a drinking problem, had become indebted to a finance company. After joining Alcoholics Anonymous, the appellant transferred his property to the respondent. Subsequently, the relationship deteriorated and the appellant sought to establish his interest in the property. The Nova Scotia Court of Appeal, agreeing with the trial Judge, concluded that since the purpose of the transfer scheme was to provide security for both the respondent and the appellant's and respondent's 16 year old daughter, the "juristic reason for the enrichment was the intention of the parties to exclude the operation of a constructive trust". Obviously there was no actual intention to exclude the operation of constructive trust but the actual intention or underlying purpose of the transfer was incompatible with the imposition of a constructive trust.

Therefore, as a general rule, constructive trusts are and should be sensitive to the intentions of the parties. This allows the parties to arrange their proprietary affairs in a manner which suits their needs and reflects their own personal values. The law of constructive trusts would be overly intrusive if it were to ignore such arrangements.

\section{G. LIMITS OF JURISTIC JUSTIFICATION}

In formulating juristic justification, the primary focus of the courts should be the narrow question of fairness as between the parties. Courts should consider whether, having regard to the particular circumstances giving rise to an enrichment and to subsequent events, it is fair for the defendant to retain the benefit. Courts should not use the analytical element of juristic justification to reform fundamental socio-economic policy. The decision to utilize the legal system as an instrument of social welfare policy or fundamental economic reform should lie exclusively in the legislative arena. This view is reflected in the recent case of Royal Bank of Canada v. 216200 Alta. Ltd. ${ }^{194}$ By contrast, Sharpe v. Sharpe ${ }^{195}$ could be construed as authorizing the courts to resolve the issue of unjust enrichment on the basis of social welfare considerations.

Absent the full factual context, the decision in Sharpe v. Sharpe is astonishing and even in context disquieting. In this case, the plaintiff, because of the manner in which she carried out her role as wife to the defendant and mother to their children, over a period of " 46 years, undoubtedly contributed to the acquisition of ... assets registered in the defendant's name". ${ }^{196}$ Nevertheless, the Court held that there was a juristic justification for the defendant retaining these assets: the plaintiff was not in need and the defendant had testified that if the expenses of maintaining the plaintiff exceeded her ability to pay he would underwrite any excess. The Court also pointed to the defendant's testimony that he intended to

193. Id. at 436.

194. 33 D.L.R. (4th) 80, [1987] 1 W.W.R. 545, (1986) 51 Sask. R. 146, 6 P.P.S.A.C. 277 (Sask. C.A.).

195. (1986) 25 E.T.R. 306 (B.C.S.C.).

196. Id. at 313 . 
prepare a new will in which he would designate the plaintiff to be his primary beneficiary. The first justification, that the plaintiff was not in need, can be viewed as a fundamental policy decision about the class of plaintiffs which the law of unjust enrichment will assist. The notion that non-necessitous complainants cannot succeed in actions for unjust enrichment subverts the purpose of the action, which is to restore to plaintiffs assets which have been generated by their resources. The non-necessitous plaintiff principle is patently incorrect. Indeed, Drost J. sensed the danger of the principle and emphasized the "peculiar" 197 circumstances of the case. Though circumstances may explain the result, they do not justify it.

What were these circumstances? The plaintiff was 80 years old, suffering from dementia, hospitalized and represented in the action by her committee and guardian ad litum. After recovering from an earlier illness for which she was hospitalized, she wished to return to the marital home but could only do so if she had the assistance of a professional homemaker. The defendant refused to consent to the presence of a "stranger" in the home and accordingly the plaintiff lived elsewhere. The defendant retained his emotional attachment to the plaintiff and this was manifested by the time they spent together. The plaintiff sued under the Family Relations Act and alternatively for unjust enrichment. She was unable to succeed under the statutory claim as there was no evidence of irreconcilable marriage breakdown. ${ }^{198}$ Though the decision to deny the plaintiff relief may be understandable in human emotional terms, it cannot be justified on the basis of the law of unjust enrichment. The refusal to order restitution because the plaintiff was not in need amounts to no less than a judicial redistribution of wealth. Though Drost J's sentiments may have been virtuous, I would suggest that they are misplaced and from the point of view of precedent, perhaps, even dangerous. The defendant's gratuitous promises to care for the plaintiff during her lifetime, either through inter vivos donations or through his will, also do not compel the result. These are promises of benificence and not restitution. Moreover, these promises are unsecured and unenforceable.

The preferable approach to this issue is that taken by the Saskatchewan Court of Appeal in the Royal Bank of Canada ${ }^{198 A}$ case. The plaintiff had acquired a debenture over all present and after-acquired property of a furniture retailer. This was duly registered under the Saskatchewan Personal Property Security Act. ${ }^{199}$ Prior to defaulting under the debenture, the furniture retailer had received monies from various consumers as partial or full payment of the purchase price of furniture. In a contest between various classes of these consumers and the plaintiff it was argued, inter alia, that the furniture retailer was constructive trustee of the monies for the various purchasers. The Court rejected the argument that there had been an unjust enrichment, emphasizing that the consumers and the retailer stood in a commercial relationship based upon a sale that took

197. Id.

198. R.S.B.C. 1979 , c. 121 s. 44.

198A. Supra, n. 194.

199. S.S. $1979-80$, c. P-61. 
place in the ordinary course of business. Essentially, the Court viewed the consumers as ordinary creditors. It was argued on behalf of the various classes of consumers, that they ought to take priority over the commercial lender because "the commercial lender is far better able to protect itself from loss and to absorb the loss should one occur". ${ }^{200}$ The Court refused to consider this submission stating that this ". . . may be true but, in the circumstances of this case, if such protection is to be provided [for consumers] it is for the legislators to provide and not the courts". ${ }^{201}$ This is clearly the correct approach. The degree to which consumers are protected by law is a fundamental question of policy which should be determined by the legislature and not the courts.

It might be argued that the suggestion that courts cannot justify a return or retention of benefits on the basis of broad social or economic policy belies the reality that they are constantly engaged in this process. After all, by allowing restitution of contributions in the nature of domestic services the courts have fundamentally altered family relationships and, at least partially converted them into economic unions. However, it must be remembered that in characterizing domestic services as a form of contribution, the courts are merely recognizing the relatively objective economic fact that such contributions entail opportunity costs and, therefore, can legitimately be viewed as deprivations. There is no greater public policy content in recognizing that the provision of domestic services is a deprivation, than there is in recognizing that the provision of money or property is a deprivation. The former form of contribution is simply more subtle than the latter form. Moreover, ultimately the courts are not compensating plaintiffs because they have experienced deprivation; rather they are being compensated because their efforts have enriched defendants. Opportunity costs without enrichment cannot and should not be compensated for under the law of unjust enrichment. ${ }^{202}$ It is suggested, therefore, that in providing restitution for contribution of domestic services the courts are not transgressing beyond the realm of socioeconomic policy which is appropriate for the judiciary. If courts were to allow such restitution because domestic services are provided by an economically disadvantaged group in society, or because, in their view, cohabitation relationships should be treated as economic unions or, indeed, as compensation for lost opportunity costs, they would be stepping beyond the tolerable limits of judicial discretion. Similarly, if a court were to refuse restitution on the ground that this would alter the traditional nature of cohabitation relationships, this too would be going beyond the pale. The legitimate task of the courts in cases involving domestic services is to recognize the hidden economic reality of these contributions. The reality is that they prejudice the contributor and enrich the contributee.

200. Supra, n. 194, at W.W.R. 556.

201. Id.

202. It will be recalled that "deprivation" in unjust enrichment terms necessarily entails an enrichment. See the text at 417 . This is appropriate since the underlying purpose of the law of restitution is to cause defendants to disgorge benefits which they ought not to keep. Courts should not compensate for lost opportunity costs in the absence of enrichment. Such a step would have a dramatic and pervasive socio-economic effect and, therefore, requires legislative consideration. 


\section{REMEDYING UNJUST ENRICHMENT: THE PROPRIETARY AND PERSONAL REMEDIES}

\section{A. THE PRESUMPTION IN FAVOUR OF THE PERSONAL REMEDY}

Equity is an inherently discretionary regime. Even the trust, the heart and soul of equity, is subject to this regime and will not be enforced when this would be contrary to the dictates of conscience. In Canada where trust beneficiaries with "unclean hands" have sought to enforce their trusts they have generally, ${ }^{203}$ but not always, ${ }^{204}$ found the courts unreceptive to their claims. Obviously in the unclean hands cases the courts, exercising equitable jurisdiction, have been actively engaged in dispensing a discretion responsive to the particular facts before them.

That the law of equitable remedies is subject to the same overriding discretion cannot be doubted. However, both the theory emanating from and the practice of courts of equity have provided guidance (albeit insufficient guidance) as to how the remedial discretion will be exercised. For example, it has been a long standing principle of equity that presumptively relief should be personal rather than proprietary. ${ }^{205}$ It has been suggested that this principle of presumptive relief has no substantive merit and is merely a product of equity's political struggle to expand its jurisdiction by not provoking a jurisdictional crisis between itself and common law. ${ }^{206}$ There may be some basis to this historical theory of the genesis of the presumption. But equity's preference for the personal remedy can be justified on the basis, inter alia, of concern for third parties who might be affected if equitable proprietary relief was granted routinely and, more importantly, on the basis of fairness to the defendant. Obviously, proprietary relief is far more intrusive on a defendant than is an award of monetary damages. Canadian courts in the past have more than paid lip service to the presumption in favour of personal rather than proprietary relief. In $R u f f v$. Strobel, for example, Lieberman J.A., after a substantive analysis of both the legal presumption in favour of personal relief and the facts before him, rejected the applicability of the proprietary remedy of constructive trust because "adequate personal remedies were at the disposal of the respondent". ${ }^{2 m}$ In the post-Pettkus v. Becker era, Canadian courts, at least in the non-cohabitation context, have continued to articulate and apply the presumption that a remedy should be personal. In the Zaidan case, Barr J. stated that "[e]ssentially a constructive trust will arise where an alternative is an unjust enrichment of the defendant at the expense of the plaintiff and there is no other effective remedy."208 [Emphasis

203. See, for example, Schuerman v. Schuerman (1916) 52 S.C.R. 640 and Maysels v. Maysels (1975) 64 D.L.R. (3d) 765; affg. (1974) 45 D.L.R. (3d) 375 (S.C.C.).

204. See, for example, Goodfriend v. Goodfriend [1972] S.C.R. 640, 22 D.L.R. (3d) 699.

205. See Ruff v. Stroebel (1978) 86 D.L.R. (3d) 284, [1978] 3 W.W.R. 588 (Alta. S.C.A.D.) and McClean's discussion of this point in his comment on Pettkus v, Becker, supra, n. 14, at 172173.

206. Id. McClean at 173.

207. Supra, n. 205, at D.L.R. 293.

208. Supra, n. 126, at 289. 
mine] Though it appears from the form of the Court's final order ${ }^{209}$ that Barr J. is merely awarding the plaintiff monetary damages, this is not entirely clear as his judgment purports to apply "the doctrine of constructive trust". ${ }^{210}$ It is suggested that what Barr J. must have meant is the doctrine of "unjust enrichment".

In the family cases, while monetary damages have been awarded to successful plaintiffs, in practice the primary form of relief seems to be the constructive trust. In Pettkus v. Becker the Supreme Court of Canada did not specify why it ordered the proprietary form of relief in preference to monetary damages. Lower courts, perhaps not surprisingly, have obediently adopted the Supreme Court's approach to relieving unjust enrichment through the use of the constructive trust and have not formulated the basis for the exercise of their discretion. Even in Sorochan v. Sorochan, the Supreme Court provided only minimal guidance as to the requirements which would have to be satisfied before a proprietary order could be obtained. Precisely how the Court arrived at its conclusion that Mary Sorochan was entitled to a blended order of both proprietary relief and monetary damages ( $1 / 3$ of the farm and $\$ 20,000$ reduced to $\$ 15,000$ if paid within six months) can only be a matter of speculation. ${ }^{211}$

In some instances, the use of the proprietary remedy of constructive trust is wholly inappropriate. In Caratun v. Caratun it will be recalled that Madam Justice Van Camp imposed a remedial constructive trust on a dental license to the extent of a proportion of its capital value. In technical terms this is insensible. The remedial constructive trust is a turst for conveyance ${ }^{212}$ and, of course, a dental license is inalienable. ${ }^{213}$ It may be that the intention of Van Camp $\mathrm{J}$. in imposing the constructive trust was to secure the personal obligation of Mr. Caratun to pay his wife a monetary sum representing his enrichment. Indeed, it is suggested that the desire to secure monetary awards is the basis of the general preference in family cases for the proprietary remedy over the personal remedy. However, because of the inherent inalienability of the professional degree, the use of the constructive trust as security is ineffectual.

In my view, the courts are justified in departing from the presumption in favour of personal relief, at least in the family cases. Though there may be drawbacks to the defendant and third parties in awarding proprietary relief, these disadvantages are outweighed by securing for the plaintiff the benefits of their courtroom success. The securing of judicial awards is

209. Id. at 294.

210. Id.

211. Dickson C.J. affirmed the order of the trial Judge. No reasons for judgment were issued by the trial Judge who entered only an order into the record. It is interesting to note, as Dickson C.J. observed, that neither party appealed the trial Judge's award in respect to quantum. See supra, n. 47, R.F.L. at 242.

212. Waters, Law of Trusts in Canada, supra, n. 5, at 388.

213. The inalienability of a professional license was noted in the case of Jirik v. Jirik (1983) 37 R.F.L. (2d) 385 (B.C.S.C.). This point and this case were cited with approval by Killeen J. in the recent case of Linton v. Linton, supra, n. 167, at 458 . 
advantageous to the entire system because it reduces the transactional costs of enforcing awards. Insofar as third party interests are concerned the doctrine of "bona fide purchaser for value without notice" protects these interests. In the commercial context different considerations may apply because of the potentially serious consequences of tying up particular business assets.

\section{B. PROPRIETARY REMEDIES}

Another matter which is not discussed in the cases is why the courts have chosen the proprietary remedy of constructive trust over its proprietary cousin, the equitable charge or lien. Practically speaking, the equitable lien would effectively secure to plaintiffs the intended benefits of an award. In practice, the constructive trust, often does no more. That is, only occasionally do constructive trust beneficiaries receive anything other than funds as a result of "following through" their constructive trusts. Often the constructive trust property will be sold and there will be a division of proceeds and occasionally the constructive trustee will purchase the equitable share of the successful plaintiff in the property in question. In some cases the plaintiff will acquire the trust property, but he or she will only do so by purchasing the constructive trustee's equitable share therein. Consequently in practice the constructive trust operates as a security device for the successful plaintiff. It would seem sensible, therefore, having regard to the substantive function of providing proprietary relief, for courts to impose the remedy of equitable lien rather than constructive trust. In principle this approach is also sound since the imposition of a constructive trust is more intrusive on a defendant than is an equitable lien. The constructive trust provides its beneficiary with a "strangle-hold" on the trust property, whereas the equitable lien merely an "arm-lock". This is because an equitable lien, unlike the constructive trust, can be discharged, without the cooperation of its beneficiary, by the payment of money. Since in unjust enrichment cases defendants are not generally wrongdoers or guilty of moral turpitude, the standard form of relief should not be particularly heavy-handed. Having stated the theoretical position, it is true that in most family cases unsuccessful defendants will be indifferent to whether relief takes the form of the constructive trust or the equitable lien.

What are equity's minimum requirements for the imposition of a proprietary remedy? In standard proprietary actions where plaintiffs seek the return of property they must be able to identify the property they seek or satisfy the tracing requirements of law or equity. The requirements of identification or "traceability" are natural or logical requirements because in the standard proprietary action the plaintiff's allegation is that the property in question belongs to or always has belonged to the plaintiff. On the other hand, where restitutionary proprietary relief is sought, the plaintiff's allegation is different. Here the plaintiff is saying that property in the name of the defendant ought to belong in whole or in part to the plaintiff or, at least, ought to be used to secure a personal obligation which the defendant owes to the plaintiff. It has been suggested that because of the difference in the fundamental nature of true and restitutionary proprietary remedies, the major constraint of the true proprietary action, 
the requirement that property be traced or identified, does not apply to the restitutionary action. ${ }^{214}$

No doubt, in some restitutionary situations the demanding requirements of proprietary tracing may be satisfied. Monies paid in error to a wrong party will often be traceable under standard tracing principles. However, in other cases, proprietary tracing requirements cannot possibly be satisfied. Where a non-titled spouse contributes to the retention of an asset or, through his or her efforts, prevents the deterioration of an asset or, even, reduces the pace of this deterioration, proprietary tracing is unattainable. It appears, however, that Canadian courts, at least in the family cases, have rejected the strictures of the standard proprietary tracing rules. A broader concept of tracing permits a plaintiff to obtain a proprietary remedy in respect to non-proprietary contributions such as services and also financial contributions which cannot be followed under the standard rules. Goff and Jones in their text recognize that the link connecting a plaintiff's contribution to the defendant's enrichment in a restitutionary action may not satisfy the requirement of existing tracing law but may nevertheless be sufficient to warrant proprietary recovery. They state: ${ }^{215}$

... it has been said that if the defendant has gained a negative, as distinct from a positive benefit, tracing is impossible; that conclusion is impeccable if the plaintiff's claim is proprietary but should be less conclusive if this claim is in restitution.

In Sorochan v. Sorochan the Supreme Court of Canada commented on the minimum "tracing" requirements for proprietary relief. Unfortunately these comments are rather brief. The need for elaboration of the comments was skirted by the simple finding of fact that there was "a 'clear link' between the contribution and the disputed assets". ${ }^{216}$

What sort of a link is necessary? Dickson C.J. tells us that what is "primary is whether or not the services rendered have a 'clear proprietary relationship' .. . [to particular assets], to use Professor McLeod's phrase". ${ }^{217}$ Without explaining what is meant by the phrase "clear proprietary relationship", Dickson C.J. adds that "[w] wen such a connection is present, proprietary relief may be appropriate."218 Earlier in his judgment, the Chief Justice quotes from Cory J.A's statements in Murray v. Roty to the effect that the remedy of constructive trust is available whether a plaintiff's contributions are direct or indirect and also that the link between a plaintiff's contributions and a defendant's enrichment "may well" be subject to less scrutiny in the "family" cases than in the "commercial" cases. ${ }^{219}$ No doubt in both contexts direct contributions,

214. See Goff and Jones, supra, n. 7, at 60-63. See also Hazlewood v. West Coast Securities Ltd. (1974) 49 D.L.R. (3d) 46 (B.C.S.C.); varied (1976) 68 D.L.R. (3d) 172 (B.C.C.A.) where Fulton J., at 67-68, stated that in unjust enrichment actions there need not be traceable property. However, without canvassing the possibility of proprietary relief, he awarded monetary relief.

215. Supra, n. 7, at 63.

216. Supra, n. 47, at R.F.L. 239.

217. Id.

218. Id.

219. Id. at 238. 
whether in the form of money, property or services, can give rise to a clear proprietary relationship between the plaintiff's contribution and specific property of the defendant. Such a relationship will exist where the contribution has lead to the acquisition of identifiable property. It also exists where identifiable property has greater value than it would have had in the absence of the plaintiff's contribution. Where contributions are indirect, it may still be possible to establish a similar proprietary link. For example, where a defendant has a single asset (such as a house) but no income, as appears to have been the case in Novick v. Lachuk, ${ }^{220}$ a plaintiff's contribution to the maintenance of the household may be convincingly connected to the retention of the house and, perhaps, depending on the facts, the maintenance of its value. On the other hand, where a plaintiff's contribution has been indirect and the defendant is active in obtaining and disposing of many assets and as well expends monies without obtaining proprietary returns, for example, he or she frequently takes holidays, it is virtually impossible to convincingly connect the plaintiff's contributions to particular assets of the defendant. However, it is suggested that in these circumstances in the family cases the courts will likely gloss over the lack of clear proprietary relationship. Certainly, the full text of Cory J.A.'s comment on the distinction between commercial and family cases suggests that this might be the case. He stated:21
It may well be necessary and appropriate to scrutinize closely the contributions of business partners to the acquisition of property. It is unnecessary and inappropriate to scrutinize the contributions of married couples or couples in a relationship such as this one in the same way. Instead, equity and fairness should guide the courts.

One should not be alarmed by the possibility that a proprietary remedy may be available even in the absence of a genuine connection between a plaintiff's contribution and particular assets of the defendant. After all the concept of proprietary link is a logical outgrowth of the true proprietary action. The same logic does not apply in a restitutionary action where plaintiffs are asserting that particular property ought to belong to them or ought to secure a monetary award made in their favour.

When should equity and fairness, in the absence of a genuine proprietary link, give rise to the possibility of a proprietary remedy? Dickson C.J's judgment in Sorochan suggests one such situation. If a claimant had a reasonable expectation of "obtaining an actual interest in property as opposed to monetary' relief", and the defendant knew or ought to have been aware of this expectation, then proprietary relief may be ordered. ${ }^{22}$ On this point Dickson C.J. found as a fact that "Mary Sorochan did have a reasonable expectation in obtaining an interest in [Alex Sorochan's farm] . .. and Alex Sorochan was aware of her expectation in this regard". ${ }^{223}$ However, in the Saskatchewan case of Jolicoer v. LeVasseur, ${ }^{24}$ Halvorson $\mathrm{J}$., relying on Sorochan, adopted the view that even if there exists a

220. See text at $422-423$.

221. Supra, n. 90, O.R. at 711.

222. Supra, n. 47, R.F.L. at 241.

223. Id.

224. (1987) 27 E.T.R. 313 (Sask. Q.B.). 
proprietary link between the plaintiff's contribution and specific property belonging to the defendant, a proprietary remedy is unavailable unless the plaintiff can also demonstrate that he or she had a reasonable expectation of acquiring an interest in the property. ${ }^{225}$ This approach can only be based on a misreading of Sorochan. That case opens the door to the remedy of constructive trust if either proprietary connection or proprietary expectation exists. Requiring both is unsound in principle. Why should the plaintiff in a restitution action have to establish both when the plaintiff in a standard proprietary action need only establish proprietary connection?

What difference would it make if a plaintiff expects to acquire his or her fair share of assets but does not, as did Mary Sorochan, have in mind particular assets? In Jolicoer v. LeVasseur, Halvorson J. concluded that the absence of expectation of sharing in specific property was an additional reason for denying proprietary relief. ${ }^{226}$ I would suggest that the absence of such specificity in the plaintiff's intention should make little difference. As noted above in restitutionary actions equity and fairness can justify the imposition of a proprietary remedy even when there is no real connection between the plaintiff's contributions or expectations and the defendant's property. Where unjust enrichment exists, the judicial desire to provide a secure remedy to a successful plaintiff is sufficient justification to warrant the imposition of a proprietary remedy. It is suggested, therefore, that even where there is neither a proprietary connection between the plaintiff's contribution and the defendant's assets or an expectation on the part of a plaintiff of sharing in the defendant's assets, proprietary relief should be available to the successful plaintiff in an unjust enrichment action.

Ultimately the question of whether proprietary relief should be granted and what form that proprietary relief should take is a matter of judicial discretion. Courts should not feel hampered in exercising their discretion by technical proprietary doctrines or ancient ideas of appropriate presumptive relief. Glossing over proprietary connection, which Cory J.A. suggests is appropriate in the family cases, is a fictional and unnecessary exercise. Equity has the flexibility and creative potential to provide proprietary relief simply because it is efficacious and fair in the circumstances to do so. As Jessel M.R. recognized in the case of Re Hallet's Estate:27

It is perfectly well known that [equitable rules] have been established from time to time altered, improved and refined from time to time. ... No doubt they were invented for the purpose of securing the better administration of justice, but still they were invented.

Extending the circumstances in which proprietary relief can be ordered in an unjust enrichment action beyond the traditional constraints of pure proprietary actions is an important step, but not one which needs to be passed onto the legislature for development. The scope for the operation of proprietary remedies is a question of "technical lawyer's law" and it is

225. Id. at 316-317.

226. Id. at 317. Ultimately, the Court took the view that its refusal to order a constructive trust made little difference to the plaintiff because the property in question, the natural subject matter of the constructive trust, no longer existed at the date of trial. As noted in the text, it is my view that there is nothing to prevent the court from attaching a constructive trust to other property in the defendant's estate.

227. (1873) 13 Ch.D. 696 at 710 (C.A.). 
quite appropriate for courts to develop this law on their own. ${ }^{228}$ It is imperative that they do so openly and not, in some cases, by failing to scrutinize the facts to determine whether "legal requirements" have been satisfied.

\section{Timing of Acquisition of Beneficial Interest Under a Restitutionary Constructive Trust}

When does a beneficiary of a remedial constructive trust acquire his or her beneficial interest in the subject matter of the trust? The answer to this question has important practical implications to creditors of constructive trustees whether claiming on the constructive trustee's insolvency or pursuant to a security interest attaching to the constructive trustee's property. The resolution of this issue also has important implications to transferees who have acquired property from constructive trustees, constructive trustees themselves and, of course, constructive trust beneficiaries. The interest of creditors, transferees and constructive trustees is ordinarily ${ }^{29}$ best advanced if the beneficiary's equitable property is viewed as arising only upon judicial declaration of the constructive trust. Conversely, in most cases, ${ }^{20}$ the interest of the beneficiary is best advanced if his or her proprietary interest is viewed as arising at the earliest moment when a successful constructive trust application might have been made.

If one views the restitutionary constructive trust purely as a remedial device, then it is natural to conclude that the beneficiary's interest arises upon judicial imposition of the remedy. However, if one considers that the proprietary remedy of constructive trust is imposed to prevent a defendant from retaining property which ought to belong to the plaintiff, this suggests that the beneficiary's proprietary interest arises as soon as the defendant is vested with property which the plaintiff ought to own. In the recent case of McDonald v. McDonald, ${ }^{231}$ Forestell J. concluded that in an application under the Ontario Family Relief Act either party could raise the issue of constructive trust. It has been suggested that allowing either party to initiate a constructive trust argument clothes the constructive trust

228. The concept of "lawyer's law" was developed by Lord Reid in Pettitt v. Pettitt [1970] A.C. 777, (1969) 2 All E.R. 385 (H.L.) where he stated at A.C. 795 that "... I think we ought to recognize the difference between cases where we are dealing with 'lawyers law' and cases where we are dealing with matters which directly affect the lives and interests of large sections of the community and which raise issues which are the subject of public controversy and on which laymen are as well able to decide as lawyers. On such matters it is not for the courts to proceed on their view of public policy for that would be to encroach on the province of Parliament:"

229. Sometimes the constructive trustee's interest is advanced if the beneficiary's equitable interest is viewed as arising earlier. For example, where the constructive trustee is a defendant in a matrimonial property action and the property in question has fallen in value after valuation day, then it is in the interest of the trustee to assert that the claimant's equitable interest was extant on valuation day. See McDonald v. McDonald (1988) 11 R.F.L. (3d) 321 (Ont. S.C.).

230. In some circumstances where property has been burdened by substantial and necessary payments such as taxes, it might be preferable from the point of view of the constructive trust beneficiary if his or her interest was viewed as arising on the date of judicial declaration of the trust.

231. Supra, n. 229. 
with non-remedial characteristics. Professor McLeod, in his annotation to the McDonald case, has noted: ${ }^{232}$

If he [Forestell J.] is correct in this conclusion it represents a major extension of the remedial constructive trust. If the trust were purely a remedy, only the person entitled to the remedy could raise it. If it were truly an institution, like the express trust, then any intersted person could raise it.

In principle, the view that a plaintiff's proprietary interest in constructive trust property arises when unjust enrichment occurs, rather than when it is judicially declared, is sound. If a plaintiff's proprietary interest is postponed until judicial recognition of the trust, then substantive rights would be affected by what should be irrelevant and often are fortuitous factors which determine when a matter is litigated. The timing of the existence of equitable interests in property, whether such interests are a product of express trusts, non-restitutionary constructive trusts, restitutionary constructive trusts or any other principle of property law, should depend on when the substantive analytical components that give rise to the interest exist, and not procedural, financial, strategic or other considerations that affect the timing of litigation and, ultimately, the timing of judicial recognition of equitable interests. It is true that third party rights may be affected in a "retrospective" sense by judicial acceptance of the theory that equitable interests under remedial constructive trusts arise when the elements of unjust enrichment exist; but equity has developed rules, such as the "bona fide purchaser for value without notice rule", to protect the legitimate interests of third parties. It is these protective rules which should be resorted to in any contest between a constructive trust beneficiary and a third party. It makes little sense to resolve the priority of these competing applicants through the use of rules which were shaped and formulated for the entirely different purpose of determining whether and when a person has acquired a beneficial interest in property.

The American text writers, Bogert and Scott, and the Canadian cases which have explicitly or implicitly considered the issue of when the proprietary interest of a beneficiary of a restitutionary constructive trust arises, have recognized that such an interest may arise upon the enrichment of the defendant. Bogert takes the view that the constructive trust once declared operates retrospectively to the date of the enrichment. ${ }^{233}$ Scott suggests that the equitable proprietary interest of a beneficiary arises upon enrichment and, adds, the courts have a discretion as to the enforcement of the constructive trust. ${ }^{24}$ Scott's view as to the timing of the creation of the beneficiary's interest was relied on in the Chase Manhattan Bank N.A. v.

232. Id. at 322. It is difficult to assess MacLeod's point. The ability of the constructive trustee to argue constructive trust may be rationalized on the "benefit and burden" principle and does not necessarily suggest that the restitutionary constructive trust is institutional in nature. See Tito v. Waddell [1977] Ch. 106 where Megarry V.C. explores the benefit and burden principle in considerable depth.

233. G. Bogert, The Law of Trusts and Trustees, (2nd ed., Revised 1978) at s. 472.

234. See Scott On Trusts (3rd ed., 1967) v. V at s. 462.4. 
Israel-British Bank (London) Ltd. ${ }^{235}$ and recently quoted with apparent approval in the Zaidan case. Scott's view is as follows: ${ }^{236}$

The beneficial interest in the property is from the beginning in the person who has been wronged. The constructive trust arises from the situation in which he is entitled to the remedy of restitution, and it arises as soon as that situation is created. For this reason, the person who is wronged is entitled to specific restitution from the wrongdoer even though the wrongdoer becomes insolvent before suit is brought, and he is entitled to specific restitution from a person to whom the wrongdoer has transferred the property, if the transferee is not a bona fide purchaser, even though the transfer is made before suit is brought for restitution. It would seem that there is no foundation whatever for the notion that a constructive trust does not arise until it is decreed by a court. It arises when the duty to make restitution arises, not when the duty is subsequently enforced.

In Zaidan, because the City of London held a tax overpayment on constructive trust for the plaintiff, the interest produced by this trust property from the date of its acquisition by the municipality properly belonged to the plaintiff. Similarly, in Duncan v. Duncan, 237 Cooke J. concluded that half of the rental income generated by property held by the constructive trustee of the plaintiff belonged to the plaintiff, even though the restitutionary constructive trust was imposed after the income was earned. On the same principle certain payments made by the defendant constructive trustee in relation to the land were set off against the rental income, notwithstanding that these payments were made prior to the declaration of the constructive trust. Though Cooke J. made no express reference to the issue of when the plaintiff had acquired her beneficial interest in the lands registered in the defendant's name, it seems clear that he proceeded on the assumption that the interest arose as soon as it could be said that unjust enrichment existed. In the insolvency context two decisions of Canadian courts, Yorkshire Trust v. Empire Acceptance ${ }^{238}$ and Phoenix Assurance Co. of Canada v. Toronto (City), ${ }^{239}$ also implicitly adopt Scott's view as to when the beneficial interest of the constructive trust beneficiary comes into existence. Most recently the Ontario Court of Appeal in Rawluk v. Rawluk expressly approved of the view that the interest of the restitutionary constructive trust beneficiary may arise prior to the judicial declaration of trust. Grange J.A., speaking on behalf of the Court, put the matter as follows: ${ }^{240}$

We recognize that the constructive trust, with respect to claims such as the one asserted in this case, is a remedial device to prevent unjust enrichment. This, however, does not mean that the property interest arising under the constructive trust is regarded in law, as coming into existence only at the time of judicial declaration of the trust. In Hussey v. Palmer... Lord Denning M.R. said with respect to a constructive trust: "The trust may arise at the outset when the property is acquired, or later on, as the circumstances may require.

235. [1981] Ch. 105, [1979] 3 All E.R. 1025 at 1036 (Ch.D.).

236. Supra, n. 126, at 288.

237. Supra, n. 121, at 173-174.

238. Supra, n. 35.

239. (1981) 35 O.R. (2d), 16 D.L.R. (3d) 351, [supplementary reasons at (1981) 33 O.R. (2d) 457], 48 C.B.R. (N.S.) 299, 129 D.L.R. (3d) 738 (Ont. H.C.); affd (1983) 39 O.R. (2d) 680, 46 C.B.R. (N.S.) 80, 142 D.L.R. (3d) 767n (Ont. C.A.); leave to Supreme Court of Canada refused (1983) 142 D.L.R. (3d) 767n.

240. Supra, n. 158, R.F.L. at 115. See also Fletcherv.M.N.R. (1987) 28 E.T.R. 126(T.C.C.) at 133 where Sarchuk T.C.J. states that he does "not accept the view that a constructive trust does not exist until the Court so declares in the course of, for example, an action by the beneficiary against the trustee." 
This seems to be a softer position than that posited by Scott. In some undefined circumstances Lord Denning indicates that the interest of a beneficiary may only come into existence after the trust property is acquired. One such circumstance has been identified in this article and that is when the constructive trust is being utilized merely to secure a pecuniary order. Other circumstances in which the trust will arise upon judicial declaration will undoubtedly depend on the context in which the issue arises.

\section{(a) The Insolvency Context}

In the recent case of Bedard v. Schell ${ }^{241}$ it was concluded that in the bankruptcy context the restitutionary constructive trust is not a trust for the purpose of s. 47(a) of the Bankruptcy Act. ${ }^{242}$ The issue in the case was whether the plaintiff required leave of the Bankruptcy Court to continue various trust actions against her cohabitee. The plaintiff had initiated the actions prior to her cohabitee's bankruptcy. Her claims were based upon express, resulting and constructive trusts, all allegedly established or arising during the 18 years the plaintiff cohabited with the defendant. Section 49(1) of the Bankruptcy Act requires that a creditor obtain leave from the Court in order to continue any action for recovery of a claim provable in bankruptcy. However, leave of the Court is not required with respect to a trust claim based upon s. 47(a) of the Act. ${ }^{243}$ This section provides that "[t]he property of a bankrupt divisible among his creditors shall not comprise", inter alia, "property held by the bankrupt in trust for another person:" Gerein J. concluded that the plaintiff could continue to pursue her express and resulting trust claims without judicial leave but that the Court's permission was required in order to pursue her constructive trust claim. ${ }^{24}$ The reasoning underlying this conclusion was that the constructive trust is "simply a remedy to right a wrong" and is not "a substantive institution".245 This point was elaborated on by Gerein J. when he stated that a s. 47(a) trust necessarily involves trust property that is identifiable at the date of the bankruptcy. He stated: ${ }^{245}$

\footnotetext{
Section 47(a) of the Bankruptcy Act is concerned with property which at the time of the bankruptcy can be identified and segregated from the other property of the bankrupt. In the case of a constructive trust such identification and segregation cannot take place until the Court imposes the trust taking into account the claim of creditors. To ensure protection to the creditors it is best that this be done only with leave of the Court and subject to what ever conditions it may impose.
}

The trial Judge's concern that S. 47(a) trusts satisfy the standard requirement of certainty of subject matter is not new. Recent cases dealing with the viability of provincial statutory trusts as trusts under the Bankruptcy Act, suggest that the courts have placed a premium on the requirement of

241. (1987) 26 E.T.R. 225 (Sask. Q.B.).

242. R.S.C. 1970 , c. B-3.

243. Bedard v. Schell and cases cited therein, supra, n. 241, at 229.

244. Id. at 232.

245. Id. at 231 .

246. Id. at 232. 
certainty of subject matter. ${ }^{227}$ If, as these cases suggest, the absence of this certainty precludes the existence of a trust recognized by the Act, then it should follow that for the purposes of the same statute the existence of a trust will be postponed until its subject matter is ascertained. It may well be, therefore, that the privileged status of trust beneficiaries on bankruptcy, is reserved to trusts which at the date of bankruptcy have identifiable subject matter. In the Phoenix Assurance case the fund over which the remedial constructive trust was imposed was traceable. ${ }^{248}$ This fund was held to be beyond the reach of the bankrupt's creditors. The identification of the trust property in Phoenix runs contrary to Gerein J.s suggestion that in constructive trust cases certainty of subject matter cannot exist until the Court imposes the trust. Certainly, in the commercial context certainty of subject matter will frequently pre-exist judicial recognition of the trust. Is the same true in the family context?

This depends upon whether courts are prepared to ascertain or identify the subject matter of the constructive trust by utilizing proprietary tracing rules or the less onerous restitutionary tracing rules. If the proprietary rules are utilized, only rarely will property that is the subject matter of a remedial constructive trust be identifiable prior to judicial declaration of the trust. If the restitutionary tracing rules are utilized identifiable subject matter will exist far more often. Under these rules, if there is a "clear proprietary connection" between the plaintiff's contribution and a particular asset vested in the defendant or if the plaintiff has had a "reasonable expectation of proprietary benefit" in respect to a specific asset, the plaintiff will be viewed as the beneficial owner of all or part of the asset at the point of the unjust enrichment. ${ }^{249}$ Only in the absence of both proprietary connection and proprietary expectation will the remedial constructive trust lack the necessary certainty of subject matter to legitimize its special status on bankruptcy. This makes sense because where there is no connection between the plaintiff's contribution and property in the defendant's estate, the proprietary remedy, if available at all, will be imposed after the fact purely as a security device. In other words, where the trust has no "natural" connection to the declared subject matter of the trust, the trust "beneficiary" at the date of the bankruptcy is truly a mere

247. Re Clarkson Gordon Inc. and The Queen in Right of Manitoba (1986) 31 D.L.R. (4th) 701 (Man. C.A.), and British Columbia v. Henfrey Samson Belair Ltd. (1987) 13 E.C.L.R. (2d) 346; contra see Robinson, Little \& Co. (Trustee of) v. Sask. (Min. of Lab.), Sask. Q.B. (unreported, 1396 C.L.D.) Regina No. 435 \& Bankruptcy No. 7635, October 7, 1987.

248. Supra, n. 239.

249. See text at $448-451$. 
creditor undeserving of the priority given to trust beneficiaries. ${ }^{299 A}$ Treating trusts which satisfy the restitutionary tracing rules as $\mathbf{s .} 47$ trusts, has the advantage of effectuating the underlying policy of s. 47 which is to give priority to trust beneficiaries over creditors. It also avoids, what are ultimately, insensible distinctions being drawn in respect to beneficiaries of various types of trusts. Why should the contributor of property or money have automatic trust status under the Bankruptcy Act as the beneficiary of a resulting trust and the contributor of labour to the building of a house in the bankrupt estate not have the same priority? Why should the framing of a case under the fictitious doctrine of the common intention resulting trust give the trust beneficiary an advantage over the remedial constructive trust beneficiary whose substantive claim is the same? Surely the types of trusts which have priority under the Bankruptcy Act should not be determined on the basis of classification per se. Even though the restitutionary constructive trust operates remedially, it is nevertheless a trust and, in some instances, as the aforementioned authorities indicate, it is a trust which springs into existence prior to judicial declaration.

It may well be that Canadian courts will ultimately adopt the cautious and conservative approach of Bedard v. Schell by reserving to trust status (for the purposes of the Bankruptcy Act) only express and resulting trusts. From a policy point of view this restrictive approach may give effect to the widespread conviction, likely shared by Gerein J., that: ${ }^{250}$

The equities between the claimant and the depriving, unjustly enriched party are not necessarily the same as those between the claimant and the depriving party's creditors, or the claimant and the depriving party's successor in title.

However, this and other policy or pragmatic ${ }^{2 s 1}$ concerns should be reflected in the content of bankruptcy law and not the law of trusts.

\section{(b) Third Party Transferees}

Concluding that the creation of the constructive trust may pre-date judicial recognition of the trust can create thorny problems for transferees of property from potential constructive trustees. Such transferees take free and clear of the claim of beneficiaries only if they are "bona fide

249A. For a thorough and excellent discussion of the policy considerations underlying the issue of priority on bankruptcy of claimants in restitutionary actions, see Professor David M. Paciocco's article, "A Remedial Constructive Trust: A Principled Basis for Priorities Over Creditors", presently pending publication. See especially pages 61-63 where he expresses the view that in the cohabitation context proprietary relief should be reserved exclusively to plaintiffs who contribute in the expectation of receiving a proprietary interest. This is at variance with the opinion of this writer. Such a restrictive approach may invite fictional findings of fact reminiscent of the common intention resulting trust cases. See text at page 412. Moreover, why should the proprietary claimant who traces his or her property to a specific item of property obtain proprietary relief, but the restitutionary claimant who can demonstrate a nexus between his or her contribution and specific property be denied this form of relief. See also the text at page $\mathbf{4 3 2}$ where, in a different context, I argue that expectation of receiving a benefit, either proprietary or pecuniary, should not be indispensible to succeeding in an action for unjust enrichment. Similarly, making proprietary expectation a condition precedent to obtaining proprietary relief would exaggerate the importance of this fact.

250. Supra, n. 5 at 396.

251. For example, the fear of collusive actions between the bankrupt and his or her cohabitant. 
purchasers for value without notice". It may be that nothing less than knowledge that a claim is being made against the transferred property will suffice to undermine this status. Indeed, even when a transferee has notice of an equitable claim against a particular property, the case of Carl Zeiss Stiftung v. Hubert Smith ${ }^{252}$ may preclude the non-titled party from claiming against the property on the basis of the "doubtful equity" notion. That is, it may be that transferees are only bound by claims of non-titled parties where they know or should know that the claim is "well founded". ${ }^{253}$ However, since equity is still fundamentally pre-occupied with matters of conscience, ${ }^{254}$ if a transferee is or should be aware that a claim may be asserted against particular property, the transferee should be viewed as taking with notice. This does not mean that transferees take with notice if they merely have knowledge that a vendor is a party to a cohabitation relationship and that a non-titled party has contributed to the property in question. Such knowledge is insufficient to taint the moral conscience of the transferee to the point where the non-titled party should be viewed as having a superior equity to that of the transferee. However, where the transferee or, perhaps, his agent is in the peculiar position of being familiar with the law of unjust enrichment, knowledge of circumstances which may give rise to a remedial constructive trust could well amount to notice. ${ }^{2 s s}$

\section{QUANTIFICATION OF REMEDIES}

The underlying purpose of the remedial aspect of the law of unjust enrichment is to cause the defendant to disgorge money or property attributable to the plaintiff's contribution. Accordingly, quantification of either the personal or proprietary remedy should focus on the actual

252. [1969] 2 Ch., (1969) 2 All E.R. 367 (C.A.).

253. Id. All E.R. at 383 per Edmund-Davies L.J.

254. Equities continued pre-occupation with matters of conscience was recently discussed and affirmed in the case of Re Montagu's Settlement Trusts [1987] Ch. 264, (Ch. D.). This case concerned the issue of whether a recipient of trust property was a constructive trustee. The recipient was a volunteer and not a purchaser and it was alleged that he took with knowledge of the trust. In a series of statements, Megarry V.C. stressed the contemporary importance of conscience to disputes which are resolved on the basis of equitable principles. At p. 277 he stated that in ". . . determining whether a constructive trust has been created, the fundamental question is whether the conscience of the recipient is bound in such a way as to justify equity in imposing a trust on him." He also noted at p. 278 that "today there is something of a tendency in equity to put less emphasis on detailed rules that have emerged from the cases and more weight on the underlying principle that engendered those rules, treating the rules less as rules requiring complete compliance, and more as guidelines to assist the court in applying the principles.' Accordingly, he stated of the important case of Baden, Delvaux and Lecuit v. Societe General pour Favoriser le Developpment du Commerce et de l'industrie un France S.A. [1983] B.C.L.R. 325, that “. . . although I readily approach the ... categories of knowledge set out in Baden as useful guidelines, I regard them primarily as aids in determining whether or not the Duke's conscience was effected in such a way as to require him to hold any or all the chattels that he received on constructive trust:"

255. In Re Montagu's Settlement, Id. at pp. 282-283 Megarry V.C. refused to attribute the knowledge of an agent/solicitor to his principle. The principle, the transferee of trust property, was a volunteer. Megarry noted that the solicitor was acting generally for the transferee and was not employed in the particular transaction to investigate the title of property acquired by the transferee. 
amount of unjust enrichment. That this focus is central is reflected by the following comments made by Dickson C.J. in Pettkus v. Becker: ${ }^{236}$

Although equity is said to favour equality, as stated in Rathwell it is not every contribution which will entitle a spouse to a one-half interest in property. The extent of the interest must be proportionate to the contribution, direct or indirect, of the claimant. Where the contributions are unequal the shares will be unequal.

In the cohabitation cases a finding of unjust enrichment should not be utilized as a pretence to divide the defendant's estate on the basis of quantification principles found in matrimonial property legislation. Extending these statutes beyond their present limits - even if a different presumptive or variable fractional share is adopted - must be the exclusive prerogative of the legislature. Unfortunately, some cases can be viewed as quantifying awards on the basis of some vague notion of entitlement to an equitable share. As noted earlier this may well explain the results in the Sorochan case. ${ }^{257}$ Other cases may be viewed as quantifying awards on a palm tree basis. For example, in Caratun v. Caratun, in valuating the plaintiff's contribution to her husband's dental license Van Camp J. simply concludes that "[o]n all the evidence before me I would find that her contribution to the obtaining of the licence should be valued at \$30,000.00'”2ss Similarly, in Wilson v. Monroe, McKenzie J., with virtually no elaboration, concludes that the plaintiff is entitled to $15 \%$ of a house and orchard. ${ }^{259}$ Having regard to Martland J's admonition (and the wide spread fear) that unjust enrichment law will introduce the specter of subjectively based justice, such a conclusory approach is particularly unfortunate.

Direct contribution of money, property and services can readily be quantified, the latter through the use of traditional quantum meruit principles. Precise details of the factors giving rise to the award, including the amount of service and level of compensation for the service, should be clearly set out. If there is consequential enrichment, because property to which the plaintiff has contributed has risen in value, the proportion of the plaintiff's contribution to this enrichment should also readily be capable of precise ascertainment. Similarly, if the plaintiff's contribution has liberated the defendant's funds and this has permitted the defendant to acquire property which has risen in value, the proportion of the plaintiff's contribution can be ascertained. The adoption of a two-step analysis, focusing first on the direct enrichment of the defendant and then on consequential enrichment, if any, will undoubtedly enhance the credibility of the quantification process.

256. Supra, n. 1, at S.C.R. 852-853.

257. However, it should be remembered that in Sorochan, Dickson C.J. made it clear that neither of the parties challenged the trial Judge's quantification of the award. See supra, n. 211.

258. Supra, n. 164, at 357.

259. Supra, n. 51. McKenzie J. does tell us at 183-184 that in quantifying the award he has "not forgotten" a sum of money given by the defendant to the plaintiff's parents and that he has considered a number of cases "no two of which are alike or similar to this one". These cases are summarized by McKenzie J. on a chart of 185-188. A review of the chart demonstrates vividly the difficulty of obtaining guidance from other cases on the quantification issue. 
[VOL. XXVI, NO. 3

\section{CONCLUSION}

The elevation of unjust enrichment from a principle of the legal system to a cause of action has enormous theoretical and practical significance. Whereas principles may explain and even influence results, causes of action produce and compel them. Moreover, principles by their very nature are and remain general and imprecise. Causes of action, on the other hand, need definition. Insofar as the constituent elements of the action of unjust enrichment are concerned, Canadian courts have been engaged in the definitional process with considerable success. The elements of deprivation and enrichment have been very broadly defined. This is appropriate because of the breadth of purpose of the law of unjust enrichment. This law seeks to prevent economic benefits from accruing to titled parties to the prejudice of non-titled parties whose resources have generated the benefits. The third element of "causal connection" has not, to this point, been fleshed out by the courts. However, I have suggested that the tort law concept of "proximate cause" might well serve the needs of the law of unjust enrichment. The final requirement of juristic justification will require the longest period of development. So far, the courts have been guarded in providing juristic justifications for retention or return of enrichments. With the exception of the cases of Sharpe v. Sharpe and Sorochan v. Sorochan and, perhaps, the area of quantification of awards, the fear of palm tree justice has proved to be unfounded. In the domestic services cases the courts have not made subjective value judgments about whether, as a matter of social policy, contributors of the services should be compensated. Rather, the courts have merely recognized that these services prejudice those who provide them and enrich their cohabitants. The only value judgment which courts have made in the context of the domestic services cases lies at the heart of the concept of unjust enrichment and that is that restitution is presumptively justified when one person has received the economic benefits of another's services. In substance, this value judgment is no different than that involved in the invigorated presumption of resulting trust where restitution is prima facie justified when one person gratuitously receives the property of another. The only difference between these two situations lies in the nature of the benefits acquired.

If the theory presented by this article relating to onus of proof is correct, then the mode of analysis in unjust enrichment cases is analogous, although not perfectly so, to Charter cases. Under the Charter, the "twostep" analysis is a familiar one. First, it must be established that there has been an interference with one of the fundamental rights or freedoms listed in the Charter. The onus of proving such interference is on the complainant. If the complainant discharges this onus, a presumptive violation of the complainant's rights exists and the onus then shifts to the government to provide justification for the violation of the rights. Similarly, in the realm of restitution the onus is on the complainant to establish a presumptive case of unjust enrichment by proving that there has been a deprivation and a causally connected enrichment. If this onus is discharged then the burden shifts to the defendant to justify the continued retention of benefits. But here the analogy breaks down somewhat since in Charter cases courts are mandated to explore whether a violation of a Charter protected right can be justified in a free and democratic society. Justification includes social, 
economic and other fundamental policy reasons which warrant the violation in question. However, as emphasized in this article, juristic justification for retention of an enrichment cannot be based on broad social or economic policy. Rather, juristic justification is concerned with the narrow question of whether, in light of the particular circumstances giving rise to the defendant's enrichment and subsequent events, it is fair for that enrichment to be retained. In both Charter and unjust enrichment cases, where there is no justification for either the violation of a complainant's fundamental rights or the retention of a complainant's contribution, courts are required to take a third step. This final step is imposing an appropriate remedy. Under both the Charter and the law of unjust enrichment, courts have a considerable discretion as to the appropriate remedy. In the case of unjust enrichment when this final remedial step has been reached, restitution is in order and the only legitimate remaining questions are whether restitution should take the form of an award of monetary damages or a proprietary form and, if the latter is appropriate, which particular proprietary remedy best serves the needs of justice. ${ }^{250}$ Unfortunately, in some cases this final remedial step has been merged with the substantive content of unjust enrichment and where specific property could not be traced to a plaintiff's contribution both proprietary and personal relief were denied. This article has suggested that inability to trace property should not preclude personal relief and, depending on context, perhaps, not even preclude proprietary relief. Undoubtedly, this latter suggestion is controversial, but it does reflect the de facto pattern of remediation of unjust enrichment in the family cases. De facto development of law is unstisfactory. It is imperative that courts begin to articulate the factors that influence the exercise of their discretion in the area of remedies. Only then will the fog of "uncertainty and complexity"261 that hovers over the law of remedies be diminished.

This article has also emphasized the relationship between the modern law of unjust enrichment and the pre-existing law of restitution and trusts. The traditional resulting trust is merely a proprietary relationship arising from unjust enrichment. Accordingly, any difference in treatment of beneficiaries of resulting and remedial constructive trusts, is spurious and unwarranted. However, the concept of unjust enrichment is not a magic elixor which explains the conceptual basis of all trusts and in particular constructive trusts previously recognized by the law. The profession's familiarity with these latter institutional trusts must continue. Similarly, lawyers will be doing their clients a disservice if they ignore the large body of restitution law established before the advent of the case of action of unjust enrichment. This body of law provides a time-tested resource of ideas relating to principles of unjust enrichment. However, a slavish and uncritical adherence to this law may well give rise to the wrong results.

In the eight years which have elapsed since the landmark decision of Pettkus v. Becker unjust enrichment has developed into a vital force in the

260. The quantification of the award, whether it takes a personal or proprietary form, will also have to be made.

261. Supra, n. 7, at 42 . 
private law system. It is a welcome addition to the law of obligation primarily because it is sensitive to the subtleties of unfair acquisition of property and wealth. To this point its greatest impact has been in the family context, though in the commercial sphere it has also performed the role of preventing windfall economic benefits from unjustly accruing to one party at the expense of another. Its evolution as a de jure doctrine, as this article has attempted to demonstrate, has not been without its problems. However, the scale of benefit has been so great that it is hardly conceivable that justice could properly be administered without it. 